\title{
A CONTROLLED STUDY OF THE EFFECTS OF TONSILL-
}

\section{ECTOMY AND ADENOIDECTOMY IN CHILDREN}

\author{
BY \\ W. J. E. McKEE` \\ From the Children's Department, Farnborough Hospital, Kent.
}

In the past, tonsillectomy has been regarded as a proper procedure to relieve a variety of illnesses, of which the most generally accepted were recurrent throat infections. It was shown by Glover (1948, 1950) that there was a large geographical and social variation in the frequency of operation. Although this may have been due to differences in need, it is more likely that it was due to different standards of assessment of the need.

It is widely accepted that the operation has good results, but this opinion is based on indefinite criteria. Kaiser $(1931,1940)$ showed a reduction in tonsillitis and sore throat for a period of 10 years from operation, and a reduction in colds and otitis media for the first 3 years. Epstein (1937) found that the best results of operation were obtained in children who had cervical adenitis and that there was only a slight improvement in those presenting with recurrent head colds. Godwin (1953), Walker (1953), Johnston and Watkins, (1954), and LeRiche and Stiver (1957) showed a benefit from removal of tonsils. These results have not been confirmed by Merts (1954), McCorkle, Hodges, Badger, Dingle, and Jordan (1955), or in the earlier investigation into "Epidemics in Schools" (M.R.C., 1938) sponsored by the Medical Research Council; these workers found no real difference in the incidence of respiratory infections in children whether they had undergone tonsillectomy or not. At the other extreme, Paton (1943) found that tonsillectomy was responsible for an overall increase in respiratory illness in girls. Illingworth (1950) suggested some of the sources of error in these studies which could explain the inconsistency of their findings. Meanwhile the operation is performed widely despite the opinions expressed by those who question the value of an operation to remedy a condition which is in any case

* Present address: South East Metropolitan Regional Hospital Board, 40 Eastbourne Terrace, London, W.2. self-limiting (Fry, 1957). The effort expended in terms of hospital staff and accommodation is large.

The mortality due to common respiratory infections is small, but tonsillectomy is not without risk. The Registrar General's statistical reviews for England and Wales show that the number of deaths ascribed to Hypertrophy of the Tonsils and Adenoids fell from 71 in 1948 to 16 in 1961 ; it is possible that these figures may not represent the total mortality. Statistics for the U.S.A., 1950-55 (quoted by Wolman, 1956) suggest a mortality somewhere between 1 in 1,000 and 1 in 5,000 operations. On a national scale this is considerable and it should be remembered that children undergoing tonsillectomy are not generally poor operation risks. For these reasons it seemed worthwhile to undertake a statistically controlled study of the operation. The aim was threefold:

(1) To assess the morbidity of tonsillectomy and adenoidectomy in children.

(2) To define, with at least more accuracy than is at present possible, indications or contraindications for the operation.

(3) To assess what part of any change resulting from operation can be attributed to the removal of tonsils or to the associated removal of adenoids. This is to be the subject of a later paper.

In designing the study an attempt was made to overcome the following problems:

(a) The Age Factor.-It has been shown by Van Volkenburgh and Frost (1933) and Badger, Dingle, Feller, Hodges, Jordan, and Rammelkamp (1953) that, with increasing age, a child develops more resistance to infections. As a child is older after tonsillectomy, one would thus expect to find a reduction in the incidence of respiratory illness compared with his preoperative record; statistical control is necessary to determine how much of the observed reduction is due specifically to the operation. 
The effects of operation were assessed in children of different age groups. A significant benefit in children of a limited age group can be lost if the analysis is made in respect of a wide age grouping only.

(b) Dependence on Parental Opinion.-Comparison of a child's post-operative health with the parents' assessment of the pre-operative state can allow memory failure and prejudice to invalidate the records. Similarly, too much reliance cannot be placed on infrequent post-operative inquiries about a child's health (Hadfield, 1950; Johnston and Watkins, 1954). It has been shown by Dingle, Badger, Feller, Hodges, Jordan, and Rammelkamp (1953) and Brimblecombe, Cruickshank, Masters, Reid, Stewart, and Sanderson (1958) that, with a system of frequent home visiting, reasonably accurate records can be obtained. A study of the effects of tonsillectomy employing this method of collecting data eliminates a serious source of error.

(c) Selection of Controls.-Kaiser (1931, 1940) compared tonsillectomized children with a control group who did not have the operation, but it is probable that there were differences between these groups in respect of the parents' attitude towards tonsillectomy which would bias the illness reports. In other studies, the principal comparison was between children who had undergone operation at some time previously, and others who did not have the operation. This method is justified only if it is assumed that the operation is performed on a more or less random selection of the community. It is no criticism of tonsillectomy to find that children who have the operation on account of a high susceptibility to throat infections, are no better after the operation than their more healthy counterparts of the community who do not have tonsillectomy-it is the aim of most operations to return the patients to the normal state. In the following study children selected by the same criteria were randomly allocated to either operation or control groups.

(d) Criteria for Acceptance in the Survey.-Children have been subjected to tonsillectomy for a variety of reasons, recurrent tonsillitis, frequent colds, otitis media, sinusitis, and a number of other vague conditions such as abdominal pains and failure to thrive. In studies of unselected children, the results of tonsillectomy in children with good indications for operation may be obscured by the element of dilution with others who cannot reasonably be expected to show a reduction in the illness studied. In the present work criteria for selection were decided in advance. (e) Duration of Follow-up.-In the studies of Kaiser $(1931,1940)$ the results of operation for a 3-year period did not parallel those for a longer period. In view of the increasing immunity to infection with age, a significant benefit from tonsillectomy in the early postoperative years may become insignificant when considered for a 10-year period. Nevertheless, a genuine improvement for 1 or 2 years may justify the operation in some cases, even though in later years the patients experience just as much illness as unoperated children.

The present study involved a 2-year follow-up. This could not disclose late results, good or bad, but there would be a reasonable presumption that, if all the results pointed one way, no major difference would be apparent in later years.

$(f)$ Evidence of Completeness of the Operation.Reports on the incidence of tonsil tags suggest that the operation is frequently incomplete. It is possible that in some surveys the good results of successful operation in a proportion of cases have been obscured by the poor results in associated cases with incomplete operations. In the present study an attempt has been made to assess the influence of remnants on the result.

(g) Diagnosis of Respiratory Illness.-Classification of respiratory illness by the many commonlyused terms involves a good deal of overlap. Parents? who regard an upset with nasal catarrh and sore throat as "tonsillitis" before operation may consider a clinically similar illness to be a "cold" after tonsillectomy. Bacteriological and virological studies do not assist diagnosis in the great majority of cases (Dingle and others, 1953; Brimblecombe and others, 1958). In this survey the diagnostic classification was based on predefined broad symptom-complexes.

(h) Restriction of Studies to the Respiratory Illnesses.-As so little is known about the general effects of tonsillectomy, complete health records have been used for this study.

\section{Methods}

Children referred to a surgeon for an opinion on the need for tonsillectomy divide themselves into three groups (see Table III, below).

(1) Children for whom in the present state of knowledge there is an urgent or definite need for tonsillectomy, and for whom it would be unethical to defer operation. These children have had episodes of peri-tonsillar abscess, pyrexial tonsillitis accompanied by convulsions, or flare-ups of renal or rheumatic disease. A few others have suffered frequent and severe tonsillitis over a period of several 
years despite continuous antibiotic therapy by the general practitioner.

(2) Children for whom the surgeon considers that tonsillectomy is not justified:

(a) Those referred on account of illnesses, such as common colds, coughs, or symptoms explained by an underlying allergic condition, and others who have experienced less than three episodes of probable throat infections or respiratory infections with cervical adenitis within the last 12 months.

(b) Others for whom it would be unethical to defer an operation other than tonsillectomy on account of marked deafness, recurrent or chronic otitis media, or proven sinusitis.

It was considered that children in these two subgroups could not reasonably be expected to show a benefit from tonsillectomy. To avoid dilution of others who might benefit, they were omitted from the study.

(3) Children with symptoms which might be referrable to the tonsils and might justify an operation, but without urgency. They have a history of three or more isolated throat infections or acute respiratory infections with cervical adenitis within the past 12 months, in addition to a variety of other upsetscolds, coughs, earaches, otitis media, chronic rhinitis, adenitis, allergy, and so on. It is probable that for this group some surgeons would recommend tonsillectomy and others would not. The study was confined to these children, the so-called "routine" cases, who comprised the majority of cases referred.

Children in this group who were clearly unsuitable for follow-up were excluded. Some were normally resident outside the catchment area of the survey hospitals, some were mentally subnormal, and others were at boarding or special residential schools. For statistical reasons, where two or more children in the same family were referred together for the same medical condition, only the elder child was allocated for study.

With these exceptions, all successive children in Group 3 under the age of 15 years, a total of 413 children, were accepted into the study, and divided into two categories:

(I) 231 for Early Operation.-In these cases tonsillectomy was carried out. In this study, tonsillectomy is taken to mean the combined operation, tonsillectomy with adenoidectomy $(\mathrm{T}+\mathrm{A})$.

(II) 182 for Controls (C.).-In these cases tonsillectomy was deferred for at least 2 years un- less it became urgently needed when the child was withdrawn from the survey.

The allocations were made by reference to a random allocation card using the hospital record number.

At the time of admission, a questionnaire was completed, giving details of past illnesses, accidents, and immunizations. Children were examined clinically, and radiological examinations, audiometric tests, and biochemical analyses were made where necessary. A brief inquiry of family illness was recorded. The use of a questionnaire ensured uniformity of these records, which provided a baseline for the subsequent health reports. Parents were advised how to keep records of any future illnesses of their children and the proposed 2-monthly follow-up was explained.

The children included in the survey were kept on a separate waiting list, and the operation was performed as soon as possible, the mean delay being 6 weeks. Postoperative records were started on the day of operation. However, the control children were visited from the time of admission to the survey, as the delay in operating on the other group was not predictable. In view of the seasonal variations in illness, it was thus necessary to adjust the starting date for the controls by discounting the first 6 weeks' records in each case. With the adjusted starting dates, the rates of admission of all the cases to the two categories became similar (Fig. 1), so that seasonal influence should affect them equally during the subsequent 2-year follow-up.

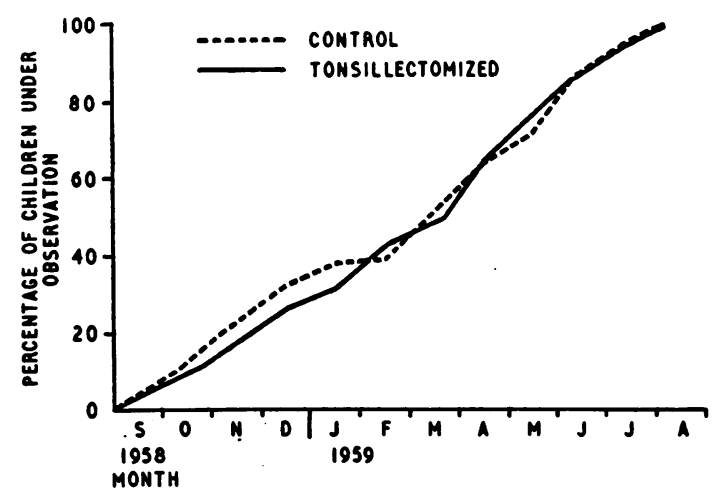

FIG. 1.-Build-up of cases and controls. Adjusted rates per cent

Home visits were made by one of two field workers specially prepared for this research, who were also trained nurses. Visits were carried out as far as possible in strict rotation, and the mean frequency was 5.8 per child per year in both control and 
tonsillectomized groups, approximately one every 2 months. At each visit an itemized questionnaire was completed giving the symptoms and duration of any illness or abnormal incident in the child's life, however slight. A further record was made giving details of the time in hospital for operation, including any complications, and at the end of the first year the children were examined by one medical officer for tonsillar remnants.

\section{ILLNESS RECORDS}

In addition to upsets causing loss of school or restriction of activity, the records contained details of minor infections and behaviour upsets; these included vague reports of malaise such as transient stomach-aches or earaches, headaches before starting school, and leg pains after exercise. It was thus necessary to have some definition of what constituted an "episode" of illness to permit the numerical evaluation of the sickness records.

An "episode" was generally taken to mean any symptom or symptom-complex abnormal for the child causing sufficient alteration of behaviour or constitutional upset for the incident to be noteworthy. This included slight coughs and colds, nasal catarrh, severe headache, or an isolated episode of vomiting, even without restriction of activity or loss of school. Indefinite reports of transient symptoms were omitted from the analysis. This definition does not cover all illness. Chronic or persisting symptoms without constitutional disturbance, behaviour and developmental upsets, operations, and accidents were also included as "episodes of illness" to complete the health picture. Eneuresis was considered abnormal when occurring in a child over 5 years of age.

One problem in recording illness is that of deciding whether an upset represents a continuation of a previous episode, or a new episode. Minor epistaxis frequently recurred over a few hours or days, boils and styes in sequences. Such incidents were considered, not in terms of the number of individual lesions, but as a clinical sequence representing one episode of illness. A similar clinical evaluation was made where respiratory or gastro-intestinal symptoms recurred after a short symptom-free period. Complications of a primary illness were considered separate episodes. Other gastro-intestinal symptoms or simple earaches associated with a respiratory infection or infectious fever were regarded as incidental symptoms of that illness.

In children undergoing tonsillectomy and adenoidectomy an allowance was made for the normal accompaniments of operation up to the end of the first week. Complications of operation, early or late, were included in the illness records.

The incidence of illness is not in itself a sufficient measure of the degree of disability. A child's health may be better after tonsillectomy despite an increase in the number of respiratory infections. The following criteria of ill-health were therefore used to assess the effects of tonsillectomy:

(1) Number of illness episodes.

(2) Confinement to bed (days). This included all periods during which a child was restricted to bed or to hospital.

(3) Loss of schooling (days). This is a precise figure, but does not take account of illness at weekends or during holiday periods.

(4) Duration of illness (days). This was defined as the total number of days during which the child was sufficiently ill to be kept at home, and not permitted to engage in normal activities. This is a useful figure since it includes illness during school holidays and in children not of school age. It gives an over-estimate of the duration of true ill-health from some infectious fevers since it includes the period of isolation after the child has physically recovered.

(5) Number of medical attendances. The number of 0 occasions on which medical advice was sought from? the patient's general practitioner, whether at theo surgery, at home, or by telephone, disregarding? attendances for prophylactic inoculations.

(6) Number of "severe" illnesses. A severe illness was taken to be an episode of one or more days' "duration", i.e. confinement, as defined above.

It was thought that, if these criteria together confirmed a particular trend, this would be a reliable guide to the effects of tonsillectomy.

It is considered likely that the 2-monthly home visits would enable details of all illnesses to be obtained, making possible a comparison of complete health records in the groups of children under observation.

\section{Classification of Illness}

The diagnosis of illness was based on pre-defined broad symptom-complexes. Records were reviewed by one doctor within a few days of each home visit, and after discussion with the field workers the illness was described as Respiratory or Non-respiratory and divided into the following sub-groups:

(A) RESPIRATORY ILlNESS.-This included acute and chronic infections of the upper and lower respiratory tract, including sinusitis but not diseases of the Eustachian tube or ear. Illness thought to be allergic in origin was assigned to a different group. 
This large group was sub-divided as follows:

(1) Cold.-An upper respiratory illness with nasal discharge and constitutional upset, whether or not associated with cough, fever, glandular enlargement, and slight soreness or irritation of the throat in the first day or two. This group included mild and severe colds, and probably a number of episodes of mild sinusitis and vasomotor rhinitis.

(2) Cough (or chest infection).--An acute episode of respiratory catarrh in which cough was the predominant symptom. This included bronchitis, tracheitis, and pneumonia, but the majority of these upsets were minor coughs.

(3) Sore Throat.-A respiratory illness with prominent sore throat, with or without associated fever, glandular enlargement, or nasal catarrh. Scarlet fever has been assigned to this group, and not to specific infectious disorders of childhood. It is likely that many episodes were not due to follicular tonsillitis; some will have been associated with bacterial, and others with virus infections of the pharynx, whether or not the tonsils were intact.

(4) Influenzal Illness.-An acute illness of epidemic nature, sudden in onset, with fever and body pains followed by respiratory symptoms. In the first year under survey there was an extensive epidemic of influenza in the area, making for some accuracy of diagnosis at the time. Nevertheless there will be some error here, as mild influenza may pass undiagnosed as such, probably simulating a cold or throat infection. It is probable that a number of these illnesses were in fact acute episodes of respiratory disease caused by other viruses. "Gastric influenza", an illness characterized by pyrexia and vomiting, was included with the gastro-intestinal upsets.

(5) Other Respiratory Illness.-This group contained a variety of upsets, including acute cervical adenitis presenting without associated disease in the respiratory tract or skin, chronic catarrh or cough, acute sinusitis, and a few doubtful minor respiratory illnesses.

\section{(B) NON-RESPIRATORY ILLNESS}

(1) Specific Infectious Diseases of Childhood.These infections are recognized by the attending doctors with a high degree of accuracy, and their diagnosis has been generally accepted. Diagnostic difficulty was, however, expected with whooping cough, and here a definition was laid down-an illness diagnosed by the general practitioner as whooping cough or occurring in association with known exposure to whooping cough, in which a spasmodic cough persisted for 4 weeks or more, or was accompanied by whooping.

Scarlet fever was not included with the specific infectious diseases of childhood.

(2) Otitis Media.--In a study based on a 2-monthly inquiry, the only reliable indication of middle ear infection is otorrhea, but many cases of otitis media will never reach this stage. We have arbitrarily defined otitis media as an episode of otorrhea, including a flare-up of chronic otitis media, or an episode or earache requiring medical attention and generally an antibiotic, which had been stated by the general practitioner to be an ear infection. Other complaints of earache in the course of other classified disease were considered to be incidental symptoms of that illness. There will thus be an underestimate, as otitis media occurring with a respiratory infection may be undiagnosed, and may settle on the treatment provided for that infection.

(3) Gastro-intestinal Illness.-This was defined as an illness characterized by diarrhoea, vomiting, or severe stomach-ache, or any combination of these symptoms, except where experienced in the course of, and inseparable from, another classified illness. The association of vomiting and abdominal pain with respiratory and other illness is well known in children and did not count as gastro-intestinal disease. This arbitrary definition includes most of the episodes of gastro-enteritis, gastric influenza, and dietary indiscretions. It will include emotional upsets representing the periodic syndrome, which cannot be separated on illness records, but will probably omit some genuine gastro-intestinal infections occurring coincidentally with another illness.

(4) Other Illness.-All the remaining "episodes" of illness were included here, infections, pyrexias, allergic diseases, behaviour upsets, accidents, and operations.

\section{Description of Population}

Children were selected from the clinics held by Mr. J. F. Lipscomb, Consultant Surgeon for Ear, Nose and Throat Diseases, at Farnborough, Sidcup, and Dartford Hospitals, which served a population, mainly urban, in outer London and Kent. Between August, 1958, and July, 1959, 413 children aged between 2 years and their 15th birthday were admitted to the trial. The sex and age distribution is is given in Table I (overleaf).

The age recorded for each child was that on the first day of the follow-up; one boy had by that time passed his 15th birthday. The average ages in the control and tonsillectomized groups were 6.48 and 
TABLE I

DISTRIBUTION OF CHILDREN STUDIED, BY AGE AND SEX

\begin{tabular}{c|c|c|c|c|c|c|c|c}
\hline $\begin{array}{c}\text { Age } \\
\text { Group } \\
\text { (yrs) }\end{array}$ & \multicolumn{3}{|c|}{ Control } & \multicolumn{3}{|c|}{ Tonsillectomized } \\
\hline & Males & $\begin{array}{c}\text { Fe- } \\
\text { males }\end{array}$ & Total & $\begin{array}{c}\text { Per } \\
\text { cent. }\end{array}$ & Males & $\begin{array}{c}\text { Fe } \\
\text { males }\end{array}$ & Total & $\begin{array}{c}\text { Per } \\
\text { cent. }\end{array}$ \\
\hline $2-4$ & 17 & 8 & 25 & $13 \cdot 7$ & 20 & 12 & 32 & $13 \cdot 8$ \\
$5-7$ & 51 & 54 & 105 & $57 \cdot 7$ & 68 & 69 & 137 & $59 \cdot 4$ \\
$8-15$ & 19 & 33 & 52 & $28 \cdot 6$ & 23 & 39 & 62 & $26 \cdot 8$ \\
\hline Total & 87 & 95 & 182 & $100 \cdot 0$ & 111 & 120 & 231 & $100 \cdot 0$ \\
\hline
\end{tabular}

6.67 years, respectively; there was a slight preponderance of females in each group.

Fig. 2 illustrates that children were most frequently referred for tonsillectomy at 5 and 6 years of age. It will be noted that only two children were under 3 years at the start, so the results in the age group 2 to 4 years are weighted in respect of children aged 3 and 4 years.

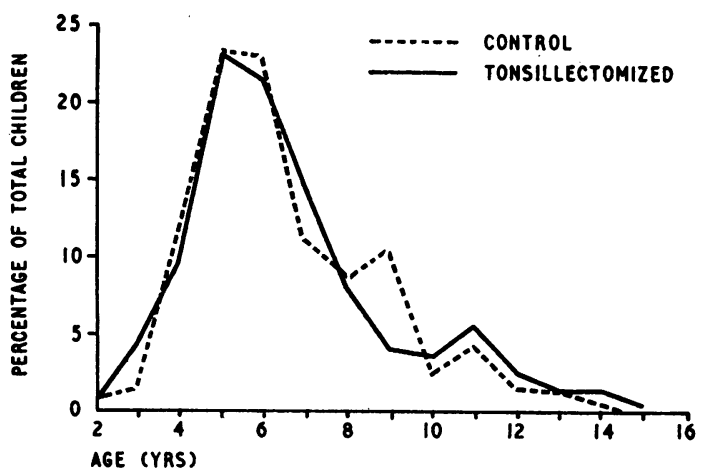

Fig. 2.-Percentage age distribution of cases and controls at start of follow-up.
Table II gives the distribution of the two groups in terms of Social Class as used by the General Register Office (1956).

TABLE II

SOCIAL GRADING OF CHILDREN STUDIED, BY FATHER'S SOCIAL CLASS

\begin{tabular}{c|c|c}
\hline \multirow{2}{*}{ Social } & \multicolumn{2}{|c|}{ Per cent. of Patients under Trial } \\
\cline { 2 - 3 } & Tonsillectomized & Control \\
\hline I & $10 \cdot 8$ & $7 \cdot 1$ \\
II & $22 \cdot 5$ & $19 \cdot 8$ \\
III & $50 \cdot 2$ & $56 \cdot 1$ \\
IV & $8 \cdot 7$ & $11 \cdot 5$ \\
V & $7 \cdot 8$ & $5 \cdot 5$ \\
\hline
\end{tabular}

Examination of these Tables shows that random allocation has given two groups which, though somewhat unequal in their total numbers, have a closely similar structure and should be comparable. The inequality of numbers resulted despite random allocation. The probability of this occurring by chance was approximately 1 in 50. Examination of the systems for numbering hospital record papers revealed no cause. An analysis of the disposal of the children (262 in all) referred to one of the hospitals with "tonsil trouble" is given in Table III.

It is possible that subconscious bias influenced the operator in excluding from the survey some children who fell into the control group, and in whom the indications for operation seemed very strong, but he was not conscious of any bias. The disproportion may have occurred by chance, but if subconscious bias was responsible, it is likely that it would favour the control group. It is noteworthy that 212 (81 per cent.) of these 262 children referred to the surgeon with "tonsil trouble" satisfied the criteria for inclusion in the third group (Table III).

TABLE III

DISPOSAL OF 262 CHILDREN REFERRED WITH "TONSIL TROUBLE" TO ONE HOSPITAL BETWEEN AUGUST, 1958, AND JULY, 1959

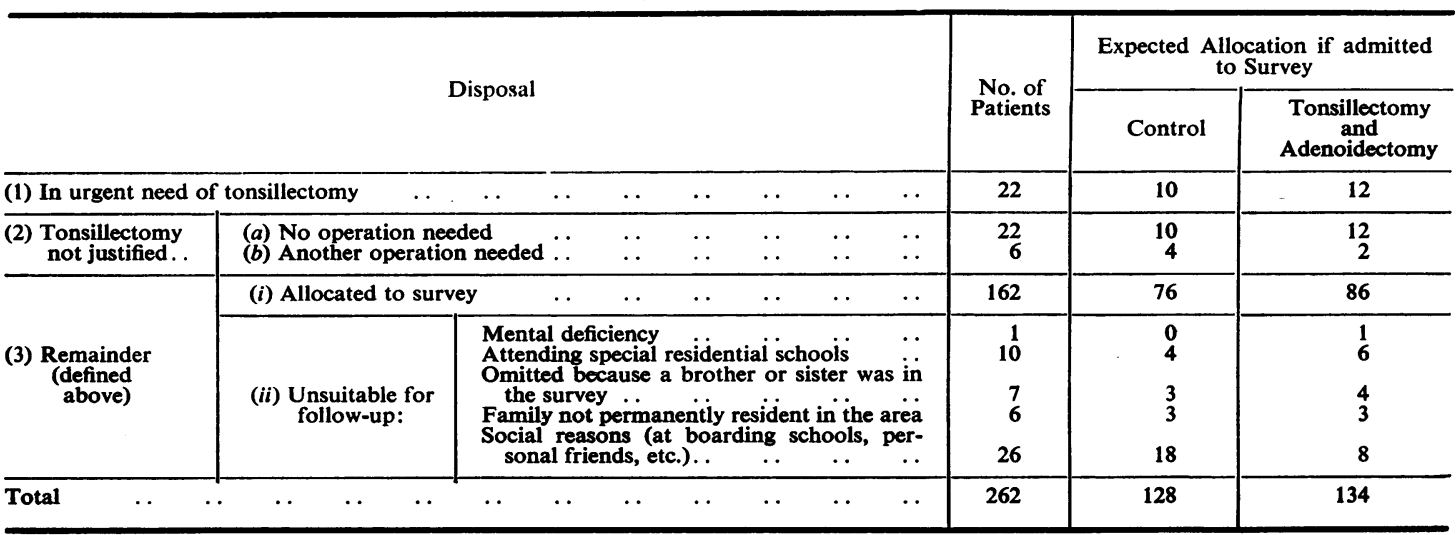


During the 2-year study, 61 cases (14.8 per cent.) were withdrawn, but of these 24 had completed one full year under observation, so that 376 were observed for 1 year and 352 for 2 years. The losses are shown in Table IV which illustrates the high level of co-operation given by parents.

TABLE IV

CHILDREN LOST TO SURVEY OUT OF THE 413 ALLOCATED

\begin{tabular}{|c|c|c|c|c|}
\hline \multirow{2}{*}{$\begin{array}{l}\text { Reason for Withdrawal } \\
\text { from Survey }\end{array}$} & \multicolumn{2}{|c|}{ 1st Year } & \multicolumn{2}{|c|}{ 2nd Year } \\
\hline & Control & $\begin{array}{c}\text { Tonsil- } \\
\text { lectomized }\end{array}$ & Control & $\begin{array}{c}\text { Tonsil- } \\
\text { lectomized }\end{array}$ \\
\hline $\begin{array}{l}\text { (A) Moved to another } \\
\text { area } \\
\text { (B) Unco o p r a ti i e } \\
\text { about visiting } \\
\text { (C) Controls withdrawn } \\
\text { to have urgent } \\
\text { tonsillectomy .. }\end{array}$ & 21 & - & - & - \\
\hline Total $\quad$. & 28 & 9 & 15 & 9 \\
\hline Per cent. Loss .. & \multicolumn{2}{|r|}{$9 \cdot 0$} & \multicolumn{2}{|r|}{$5 \cdot 8$} \\
\hline
\end{tabular}

The age distribution of these losses is shown in Table V. There was a small weighting in respect of children under 7 years of age when compared with the whole population studied.

TABLE V

AGE DISTRIBUTION OF CHILDREN LOST TO SURVEY

\begin{tabular}{|c|c|c|c|c|c|}
\hline \multirow{2}{*}{$\begin{array}{c}\text { Age } \\
\text { Group } \\
\text { (yrs) }\end{array}$} & \multicolumn{2}{|c|}{ 1st Year } & \multicolumn{2}{|c|}{ 2nd Year } & \multirow{2}{*}{$\begin{array}{l}\text { Per cent. } \\
\text { of Total } \\
\text { Losses }\end{array}$} \\
\hline & Control & Operated & Control & Operated & \\
\hline $\begin{array}{l}2-4 \\
5-7 \\
8-15\end{array}$ & $\begin{array}{r}1 \\
24 \\
3\end{array}$ & $\begin{array}{l}\overline{5} \\
4\end{array}$ & $\begin{array}{l}6 \\
6 \\
3\end{array}$ & $\begin{array}{l}\overline{7} \\
2\end{array}$ & $\begin{array}{l}11 \\
69 \\
20\end{array}$ \\
\hline Total & 28 & 9 & 15 & 9 & 100 \\
\hline
\end{tabular}

The numbers of children remaining for detailed comparison in each category were as follows:

(1) Children with completed illness records for 1 year (Total 376):

$$
\text { Control ... . . } 154
$$

Tonsillectomized 222

(2) Children with completed records for 2 years (Total 352):

$\begin{array}{llr}\text { Control _. } & 139 \\ \text { Tonsillectomized } & 213\end{array}$

\section{RESULTS}

(1) INCIDENCE OF Disease In CONTROLS

Fig. 3 illustrates the relative incidence of different groups of illness in the unoperated children during the first year of the follow-up. 1,098 episodes of illness were recorded, an average of $7 \cdot 1$ for each child,

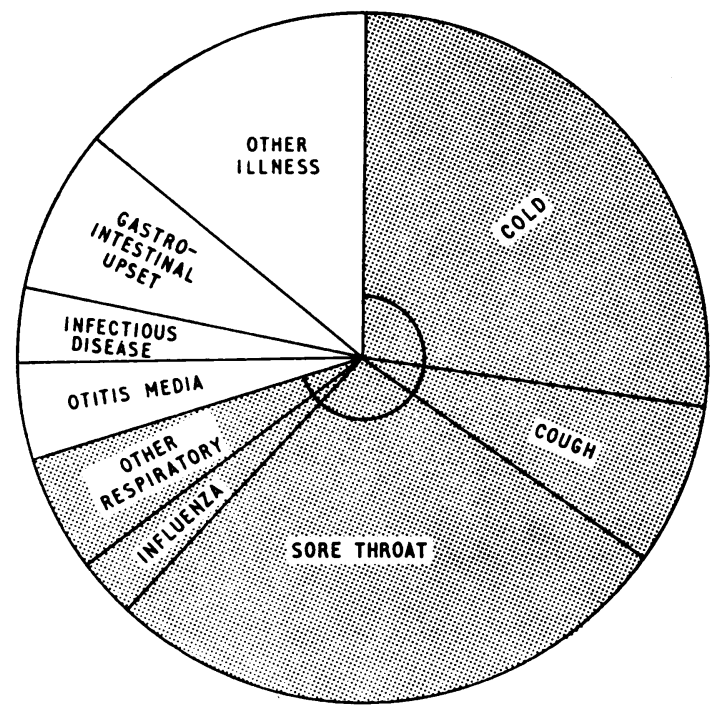

FIG. 3.-Percentage distribution of classified illness in 154 control children during first year of follow-up.

respiratory illnesses accounting for 70 per cent. These children formed a special population who had in many cases been referred to hospital primarily on account of their susceptibility to respiratory upsets, and this high rate of respiratory illness does not apply to the general community.

Table VI (overleaf) examines differences in the pattern of illness when its significance is assessed by other criteria.

The incidence of sore throat and cold was similar, but the relative severity of the former is seen in the longer periods of confinement. Almost 40 per cent. of the total duration of illness was caused by sore throats, only 15 per cent. by colds. Throat infections accounted for a higher percentage of medical attendances ( 40 per cent.) than any other classified group of illness. An equal incidence of colds required only $6 \cdot 4$ per cent. of the total medical attendances. Influenzal illness accounted for less than 3 per cent. of all illnesses, but gave a relatively high duration of illness. Ear infections comprised less than 5 per cent. of all incidents of illness, they gave a similar proportion of the total school loss, but ranked high among the illnesses for which medical attention was sought. They accounted for more than 11 per cent. of all consultations with the patients' general practitioners, which illustrates public awareness of the seriousness of otitis media. 
TABLE VI

RELATIVE DISTRIBUTION OF ILLNESS USING VARIOUS CRITERIA FOR ASSESSMENT IN 154 CONTROL CASES DURING FIRST YEAR OF STUDY

\begin{tabular}{|c|c|c|c|c|c|c|c|c|c|}
\hline & Illness & & & $\begin{array}{l}\text { Per cent. of } \\
\text { Incidence of } \\
\text { Illness }\end{array}$ & $\begin{array}{c}\text { Per cent. of } \\
\text { Total } \\
\text { Confinement } \\
\text { to Bed }\end{array}$ & $\begin{array}{c}\text { Per cent. of } \\
\text { Total School } \\
\text { Loss }\end{array}$ & $\begin{array}{l}\text { Per cent. of } \\
\text { Total } \\
\text { Duration } \\
\text { of Illness }\end{array}$ & $\begin{array}{l}\text { Per cent. of } \\
\text { Medical } \\
\text { Attendances }\end{array}$ & $\begin{array}{l}\text { Per cent. of } \\
\text { Incidence } \\
\text { of Severe } \\
\text { Illnesses }\end{array}$ \\
\hline \multirow[t]{2}{*}{ Respiratory } & $\begin{array}{l}\text { Cold } \ldots \\
\text { Cough and Chest Infection } \\
\text { Sore Throat .. } \\
\text { Influenzal Illness . } \\
\text { Other Respiratory Illness }\end{array}$ & $\begin{array}{l}\cdots \\
\cdots \\
\cdots \\
\cdots\end{array}$ & $\begin{array}{l}\cdots \\
\cdots \\
\cdots \\
\cdots\end{array}$ & $\begin{array}{r}27 \cdot 2 \\
7 \cdot 6 \\
27 \cdot 4 \\
2 \cdot 7 \\
5 \cdot 4\end{array}$ & $\begin{array}{r}11 \cdot 1 \\
12 \cdot 3 \\
42 \cdot 8 \\
9 \cdot 0 \\
0 \cdot 2\end{array}$ & $\begin{array}{r}15 \cdot 0 \\
11 \cdot 2 \\
37 \cdot 4 \\
8 \cdot 4 \\
0 \cdot 4\end{array}$ & $\begin{array}{r}15 \cdot 5 \\
10 \cdot 2 \\
39 \cdot 0 \\
7 \cdot 8 \\
0 \cdot 8\end{array}$ & $\begin{array}{r}6 \cdot 4 \\
11 \cdot 9 \\
39 \cdot 8 \\
6 \cdot 1 \\
2 \cdot 3\end{array}$ & $\begin{array}{r}22 \cdot 3 \\
7 \cdot 7 \\
40 \cdot 9 \\
4 \cdot 5 \\
1 \cdot 0\end{array}$ \\
\hline & Total ... & . & $\ldots$ & $70 \cdot 3$ & $75 \cdot 4$ & $72 \cdot 4$ & $73 \cdot 3$ & $66 \cdot 5$ & $76 \cdot 4$ \\
\hline \multirow[t]{2}{*}{$\begin{array}{c}\text { Non- } \\
\text { Respiratory }\end{array}$} & $\begin{array}{lc}\text { Otitis Media } & \ldots \\
\text { Infectious Disease } & \ldots \\
\text { Gastro-intestinal Upset } \\
\text { Other Illness }\end{array}$ & $\begin{array}{l}\cdots \\
\cdots \\
\cdots\end{array}$ & $\begin{array}{l}\cdots \\
\cdots \\
\cdots\end{array}$ & $\begin{array}{r}4 \cdot 6 \\
3 \cdot 5 \\
7 \cdot 6 \\
14 \cdot 0\end{array}$ & $\begin{array}{r}5 \cdot 8 \\
10 \cdot 7 \\
3 \cdot 3 \\
4 \cdot 8\end{array}$ & $\begin{array}{r}5 \cdot 1 \\
15 \cdot 6 \\
3 \cdot 5 \\
3 \cdot 4\end{array}$ & $\begin{array}{r}5 \cdot 2 \\
15 \cdot 2 \\
3 \cdot 1 \\
3 \cdot 2\end{array}$ & $\begin{array}{r}11 \cdot 4 \\
8 \cdot 6 \\
3 \cdot 6 \\
9 \cdot 9\end{array}$ & $\begin{array}{l}6 \cdot 4 \\
5 \cdot 8 \\
6 \cdot 5 \\
4 \cdot 9\end{array}$ \\
\hline & Total .. $\ldots$ & . & . & $29 \cdot 7$ & $24 \cdot 6$ & $27 \cdot 6$ & $26 \cdot 7$ & $33 \cdot 5$ & $23 \cdot 6$ \\
\hline
\end{tabular}

(2) Seasonal Variation in InCidence of RespiraTORY ILLNESS

The seasonal incidence of throat infections followed a different pattern from other common respiratory illness (Fig. 4). For this purpose common respiratory illness constituted the defined groups of colds and coughs. There was a period of approximately 6 months between September and March in each year during which the incidence of common respiratory illness was high. The maximum rate was approximately 33 to 39 episodes per 100 children in December or January. There was only a slight fall in the winter peaks over 3 years but the areas under the curve show a larger annual reduction. This trend could represent normal annual variations, or more likely the development of immunity with increasing age.

In this selected population of unoperated children the rate of throat infection was high at the start of the follow-up. It fell gradually thereafter without showing regular seasonal variations. It would appear that these children were referred to the E.N.T. Surgeon in a phase of high susceptibility to throat infections and progressively acquired resistance to these infections without having tonsillectomy.

The seasonal variations in common respiratory illness confirm the need for the adjustment in the starting date for follow-up of controls, so that a similar proportion of the total cases in control and operated groups were exposed to the prevailing infections at any time.

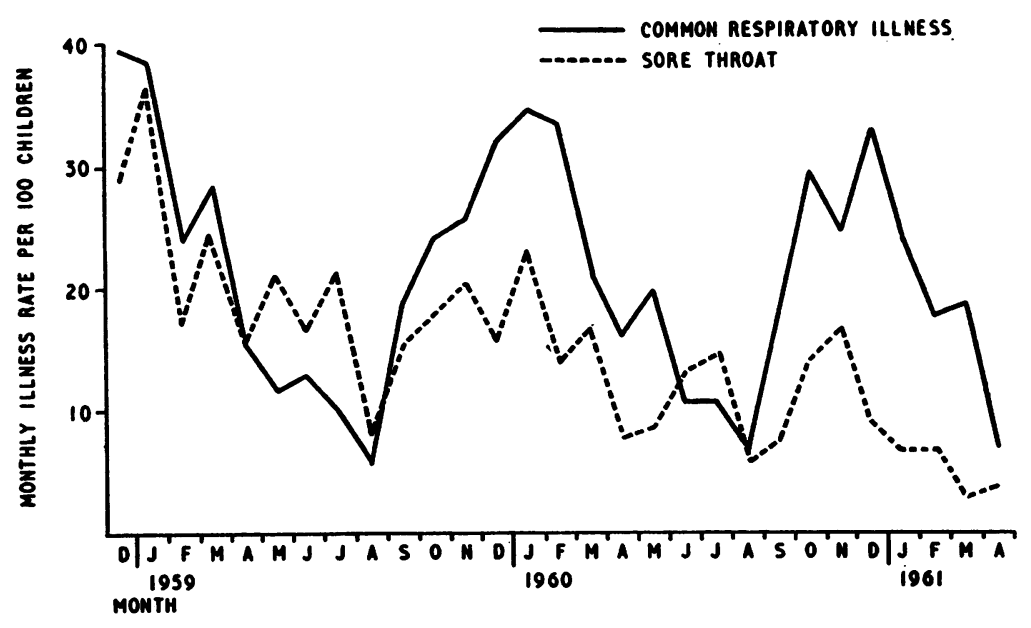

Fio. 4.-Monthly rate'per hundred children of common respiratory illness and sore throat. 
(3) COMPaRison OF Illness IN TONSILlectomized AND CONTROL CATEgories

In the first year the overall incidence of illness in the tonsillectomized children was 23 per cent. lower than in the control group (Table VII). This difference is statistically significant $(p<\cdot 01)$. A reduction of 30 to 40 per cent. when illness was assessed by other criteria, confirmed the validity of this benefit from operation. The results of the follow-up over the second year showed that this benefit was maintained. In operated children there was again a 23 per cent. reduction in the incidence of illness, and a corresponding decline in the duration of illness at different levels of severity. Smaller changes in school loss and medical attendances over the second year are not individually significant, but both criteria show a reduction of 15 per cent. in the illness of operated children compared with controls. Tonsillectomy resulted in a saving at the rate of 1,340 days illness per 100 children over the first 2 post-operative years.

(A) Respiratory Illness.-There was a statistically significant fall in the incidence of respiratory illness over 2 years as a result of tonsillectomy. Tonsillectomized children showed a reduction of more than 30 per cent. when compared with controls, from a mean of 5.0 respiratory illnesses to 3.2 in respect of the first year, and from $3 \cdot 8$ to $2 \cdot 6$ in the second year. The principal source of this improvement was the reduction in sore throats by 82 and 70 per cent. respectively for the 2 years (Table VIII). In both years tonsillectomy gave a smaller benefit through a reduction in the incidence of "other respiratory illness" as defined. This related to minor upsets for there was no corresponding benefit in this sub-group

TABLE VII

OVERALL HEALTH OF CONTROL AND TONSILLECTOMIZED CHILDREN (2 TO 15 YEARS), BY DIFFERENT CRITERIA OF ASSESSMENT

\begin{tabular}{|c|c|c|c|c|c|c|c|c|}
\hline \multirow[b]{2}{*}{$\begin{array}{l}\text { Criteria of Assessment } \\
\text { of Overall Health }\end{array}$} & \multicolumn{4}{|c|}{ 1st Year (376) } & \multicolumn{4}{|c|}{ 2nd Year (352) } \\
\hline & $\begin{array}{l}154 \\
\text { Control }\end{array}$ & $\underset{\substack{\text { Tonsil- } \\
\text { lectomized }}}{222}$ & $\begin{array}{l}\text { Difference } \\
\text { between } \\
\text { Means } \\
\pm \text { Standard } \\
\text { Error }\end{array}$ & $\mathrm{t}^{*}$ & $\begin{array}{c}139 \\
\text { Control .. }\end{array}$ & $\begin{array}{c}213 \\
\text { Tonsil- } \\
\text { lectomized }\end{array}$ & $\begin{array}{c}\text { Difference } \\
\text { between } \\
\text { Means } \\
\pm \text { Standard } \\
\text { Error }\end{array}$ & $t^{*}$ \\
\hline No. of Episodes of Illness & $7 \cdot 1$ & $5 \cdot 5$ & $1 \cdot 6 \pm 0 \cdot 3$ & $5 \cdot 26$ & $6 \cdot 3$ & $4 \cdot 8$ & $1 \cdot 5 \pm 0 \cdot 4$ & $3 \cdot 83$ \\
\hline $\begin{array}{l}\text { Confinement to Bed } \\
\text { (days) }\end{array}$ & $\begin{array}{r}8 \cdot 3 \\
17 \cdot 8\end{array}$ & $\begin{array}{r}4 \cdot 9 \\
12 \cdot 0\end{array}$ & $\begin{array}{l}3 \cdot 4 \pm 0 \cdot 8 \\
5 \cdot 8 \pm 1 \cdot 2\end{array}$ & $\begin{array}{l}4 \cdot 27 \\
4 \cdot 74\end{array}$ & $\begin{array}{r}5 \cdot 3 \\
11 \cdot 2\end{array}$ & $\begin{array}{l}3 \cdot 8 \\
9 \cdot 5\end{array}$ & $\begin{array}{l}1 \cdot 5 \pm 0 \cdot 7 \\
1 \cdot 7 \pm 1 \cdot 2\end{array}$ & $\begin{array}{l}2 \cdot 00 \\
1 \cdot 45\end{array}$ \\
\hline $\begin{array}{l}\text { Total Duration of IIIness } \\
\text { (days) }\end{array}$ & $29 \cdot 3$ & $19 \cdot 4$ & $9 \cdot 9 \pm 2 \cdot 1$ & $4 \cdot 78$ & $19 \cdot 2$ & $15 \cdot 7$ & $3 \cdot 5 \pm 1 \cdot 8$ & 1.98 \\
\hline $\begin{array}{l}\text { Nonces } \\
\text { No. of Severe Episodes }\end{array}$ & $\begin{array}{l}4 \cdot 1 \\
4 \cdot 4\end{array}$ & $\begin{array}{l}2 \cdot 9 \\
3 \cdot 1\end{array}$ & $\begin{array}{l}1 \cdot 2 \pm 0 \cdot 3 \\
1 \cdot 3 \pm 0 \cdot 2\end{array}$ & $\begin{array}{l}3 \cdot 43 \\
5 \cdot 51\end{array}$ & $\begin{array}{l}3 \cdot 1 \\
3 \cdot 3\end{array}$ & $\begin{array}{l}2 \cdot 6 \\
2 \cdot 3\end{array}$ & $\begin{array}{l}0 \cdot 5 \pm 0 \cdot 3 \\
1 \cdot 0 \pm 0 \cdot 2\end{array}$ & $\begin{array}{l}1 \cdot 44 \\
4 \cdot 20\end{array}$ \\
\hline
\end{tabular}

$*_{t}=2.59$ for Probability $P=0.01$

$* t=1.97$ for Probability $P=0.05$

TABLE VIII

MEAN INCIDENCE PER YEAR OF ILLNESS IN CONTROL AND TONSILLECTOMIZED CHILDREN (2 TO 15 YEARS)

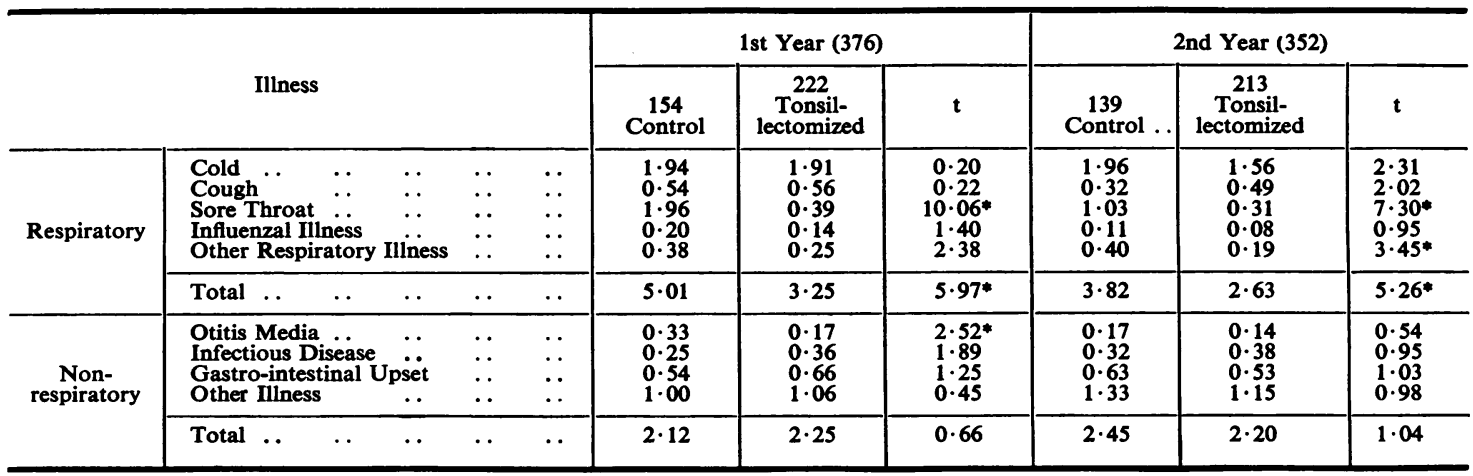

* Significant change $P<\cdot 01$ 
when assessed in terms of school loss or the medical attendances required. Nevertheless, this result may be important, for it related particularly to a reduction in chronic catarrhal illness (Table IX) which was a frequent complaint in children referred for tonsillectomy. Statistical examination of the difference in proportions of children with this complaint supports the finding that tonsillectomy relieves persisting nasal catarrh or obstruction in more than half of the affected cases.

\section{TABLE IX}

YEARLY INCIDENCE PER 100 CASES OF "OTHER RESPIRATORY ILLNESS", BY CAUSE

\begin{tabular}{|c|c|c|c|c|}
\hline \multirow{2}{*}{$\begin{array}{l}\text { Cause of Other } \\
\text { Respiratory Illness }\end{array}$} & \multicolumn{2}{|c|}{ 1st Year } & \multicolumn{2}{|c|}{ 2nd Year } \\
\hline & Control & $\begin{array}{c}\text { Tonsil- } \\
\text { lectomized }\end{array}$ & Control & $\begin{array}{c}\text { Tonsil- } \\
\text { lectomized }\end{array}$ \\
\hline $\begin{array}{l}\text { (1) Persistent nasal } \\
\text { catarrh or obstruc- } \\
\text { tion } \ldots \\
\text { (2) Chronic or persist- } \\
\text { ent cough } \\
\text { (3) Other episodes }- \\
\text { acute sinusitis, etc. }\end{array}$ & $\begin{array}{r}28 \cdot 6 \\
3 \cdot 9 \\
5 \cdot 8\end{array}$ & $\begin{array}{r}14 \cdot 4 \\
4 \cdot 1 \\
6 \cdot 3\end{array}$ & $\begin{array}{r}27 \cdot 3 \\
3 \cdot 6\end{array}$ & $\begin{array}{r}10 \cdot 8 \\
4 \cdot 2 \\
4 \cdot 2\end{array}$ \\
\hline $\begin{array}{ll}\text { Total } \ldots & \ldots\end{array}$ & $38 \cdot 3$ & $24 \cdot 8$ & $40 \cdot 3$ & $19 \cdot 2$ \\
\hline
\end{tabular}

Tonsillectomy had no influence on the occurrence of colds or coughs over the first post-operative year (Table VIII). There were small changes in opposite directions for the second year-there was a 20 per cent. lower incidence of colds, a 53 per cent. increase in coughs resulting from operation. When these two groups of illness were considered together, the mean incidence in controls was $2 \cdot 3$ episodes per year, in operated children $2 \cdot 1$ per year. This difference was not statistically significant, and it is probable that the individual differences represent overlap in the classification of these illnesses where nasal catarrh or cough is more or less predominant. Tonsillectomy did not influence the incidence of influenzal disease.

Unoperated children had a significantly higher rate of school loss on account of respiratory illness over both years. In the first year there was a reduction of 51 per cent. from operation, in the second year a 36 per cent. reduction (Table $X)$. The source of this improvement was the large reduction in throat disease. The statistics for loss of schooling showed that operation gave no benefit in respect of colds or influenzal disease. Chronic catarrhal disease, which was more frequent in unoperated children, did not commonly give rise to absence from school, so that the increased incidence noted above was not reflected here. There was a small increase after operation in school loss from coughs and chest infections seen only in the second year (Table X). It was partly balanced by an improvement in respect of colds. The increase in this illness was small in comparison with the benefit from the reduction in throat disease, and the overall respiratory record showed a 45 per cent. improvement after operation in respect of loss of schooling.

Similar benefits from tonsillectomy were found using the duration of illness and the confinement to bed as criteria for comparison with controls (Table XI, opposite).

There was a reduction of 85 and 78 per cent. respectively for the first and second years in the duration of throat disease. An increase of 1.2 days' illness from coughs over 2 years was small in comparison with the mean saving of $14 \cdot 1$ days from throat disease. No other group of respiratory illness showed an essential change, and the overall benefit

TABLE X

MEAN SCHOOL LOSS (DAYS PER YEAR) FROM RESPIRATORY ILLNESS IN CONTROLS AND TONSILLECTOMIZED CHILDREN (2 TO 15 YEARS)

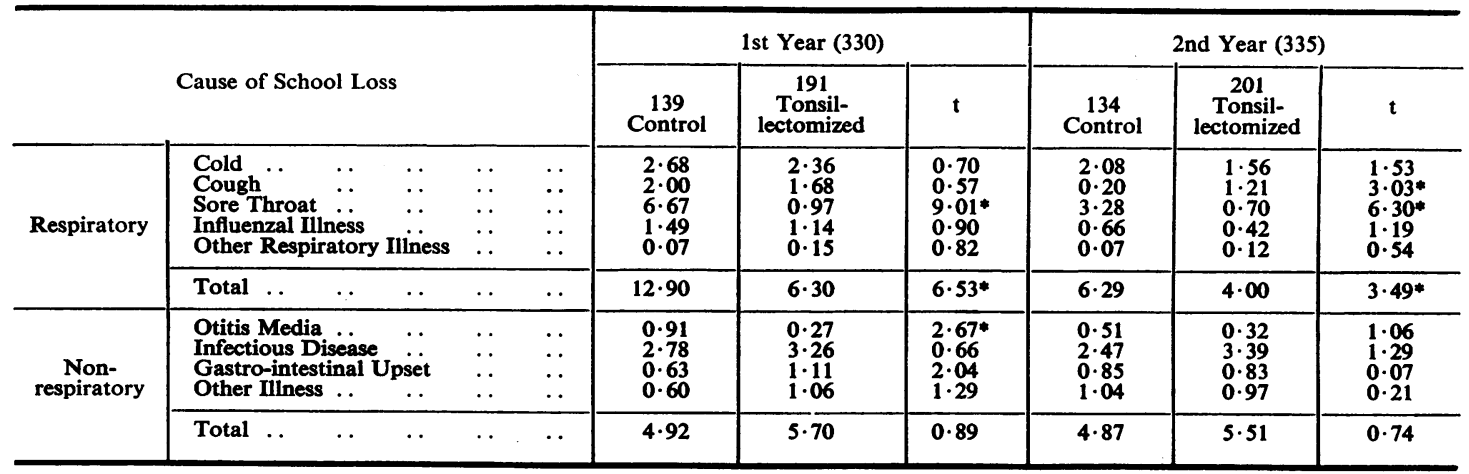


TABLE XI

MEAN ILLNESS PER YEAR IN CONTROL AND TONSILLECTOMIZED CHILDREN (2 TO 15 YEARS)

\begin{tabular}{|c|c|c|c|c|c|c|c|c|c|c|c|c|c|c|c|c|}
\hline & \multirow{3}{*}{\multicolumn{3}{|c|}{ Illness }} & & \multicolumn{4}{|c|}{ Duration (days per year) } & \multicolumn{4}{|c|}{ Confinement to Bed (days) } & \multicolumn{4}{|c|}{ No. of Severe Episodes } \\
\hline & & & & & \multicolumn{2}{|c|}{ 1st Year } & \multicolumn{2}{|c|}{ 2nd Year } & \multicolumn{2}{|c|}{ 1st Year } & \multicolumn{2}{|c|}{ 2nd Year } & \multicolumn{2}{|c|}{ 1st Year } & \multicolumn{2}{|c|}{ 2nd Year } \\
\hline & & & & & $\begin{array}{c}\text { Con- } \\
\text { trol }\end{array}$ & $\begin{array}{c}\text { Oper- } \\
\text { ated }\end{array}$ & $\begin{array}{c}\text { Con- } \\
\text { trol }\end{array}$ & $\begin{array}{r}\text { Oper- } \\
\text { ated }\end{array}$ & $\begin{array}{c}\text { Con- } \\
\text { trol }\end{array}$ & $\begin{array}{r}\text { Oper- } \\
\text { ated }\end{array}$ & $\begin{array}{c}\text { Con- } \\
\text { trol }\end{array}$ & $\begin{array}{r}\text { Oper- } \\
\text { ated }\end{array}$ & $\begin{array}{c}\text { Con- } \\
\text { trol }\end{array}$ & $\begin{array}{r}\text { Oper- } \\
\text { ated }\end{array}$ & $\begin{array}{c}\text { Con- } \\
\text { trol }\end{array}$ & $\begin{array}{r}\text { Oper- } \\
\text { ated }\end{array}$ \\
\hline \multirow[t]{2}{*}{ Respiratory } & $\begin{array}{l}\text { Cold } \quad \ldots \\
\text { Cough } \quad . \\
\text { Sore Throat } \\
\text { Influenzal Illness } \\
\text { Other Respiratory }\end{array}$ & $\begin{array}{l}\ldots \\
\cdots \\
\cdots \\
\text { ilines }\end{array}$ & $\begin{array}{l}\cdots \\
\cdots \\
\cdots \\
\cdots\end{array}$ & $\begin{array}{l}\cdots \\
\cdots \\
\cdots \\
\cdots\end{array}$ & $\begin{array}{r}4 \cdot 56 \\
2 \cdot 97 \\
11 \cdot 43 \\
2 \cdot 28 \\
0 \cdot 24\end{array}$ & $\begin{array}{l}3 \cdot 84 \\
2 \cdot 86 \\
1 \cdot 68 * \\
1 \cdot 49 \\
0 \cdot 27\end{array}$ & $\begin{array}{l}3 \cdot 28 \\
0 \cdot 45 \\
5 \cdot 70 \\
0 \cdot 88 \\
0 \cdot 11\end{array}$ & $\begin{array}{l}2 \cdot 64 \\
1 \cdot 77^{*} \\
1 \cdot 28 * \\
0 \cdot 64 \\
0 \cdot 20\end{array}$ & $\begin{array}{l}0.92 \\
1.01 \\
3.53 \\
0.75 \\
0.02\end{array}$ & $\begin{array}{l}0 \cdot 66 \\
0 \cdot 90 \\
0 \cdot 48 * \\
0 \cdot 57 \\
0 \cdot 07\end{array}$ & $\begin{array}{l}0 \cdot 58 \\
0 \cdot 22 \\
2 \cdot 01 \\
0 \cdot 30 \\
0.01\end{array}$ & $\begin{array}{l}0 \cdot 58 \\
0 \cdot 45 \\
0 \cdot 32^{*} \\
0 \cdot 27 \\
0.06\end{array}$ & $\begin{array}{l}0 \cdot 97 \\
0 \cdot 34 \\
1 \cdot 79 \\
0 \cdot 19 \\
0 \cdot 05\end{array}$ & $\begin{array}{l}0 \cdot 94 \\
0 \cdot 37 \\
0 \cdot 35^{*} \\
0 \cdot 14 \\
0 \cdot 04\end{array}$ & $\begin{array}{l}0.91 \\
0 \cdot 12 \\
0.90 \\
0.11 \\
0.06\end{array}$ & $\begin{array}{l}0.69 \\
0 \cdot 25 \\
0.23^{*} \\
0.08 \\
0.03\end{array}$ \\
\hline & Total & $\ldots$ & $\ldots$ & $\ldots$ & $21 \cdot 49$ & $10 \cdot 13 *$ & $10 \cdot 41$ & $6 \cdot 54 *$ & $6 \cdot 22$ & $2 \cdot 68 *$ & $3 \cdot 12$ & $1 \cdot 67 *$ & $3 \cdot 34$ & $1 \cdot 83^{*}$ & $2 \cdot 09$ & $1 \cdot 28^{*}$ \\
\hline \multirow[t]{2}{*}{$\begin{array}{l}\text { Non- } \\
\text { respiratory }\end{array}$} & $\begin{array}{l}\text { Otitis Media } \\
\text { Infectious Disease } \\
\text { Gastro-intestinal } \\
\text { Other Illness }\end{array}$ & $\begin{array}{l}\cdots \\
\text { Upset } \\
\cdots\end{array}$ & $\begin{array}{l}\cdots \\
\cdots \\
\cdots\end{array}$ & $\begin{array}{l}\cdots \\
\cdots \\
\cdots\end{array}$ & $\begin{array}{l}1.53 \\
4.45 \\
0.92 \\
0.93\end{array}$ & $\begin{array}{l}0 \cdot 52 * \\
5 \cdot 32 \\
1 \cdot 56 \\
1 \cdot 76\end{array}$ & $\begin{array}{l}0 \cdot 72 \\
5 \cdot 26 \\
1 \cdot 29 \\
1 \cdot 57\end{array}$ & $\begin{array}{l}0 \cdot 50 \\
5 \cdot 85 \\
1 \cdot 17 \\
1 \cdot 67\end{array}$ & $\begin{array}{l}0 \cdot 48 \\
0 \cdot 88 \\
0 \cdot 27 \\
0.40\end{array}$ & $\begin{array}{l}0 \cdot 10^{*} \\
1 \cdot 07 \\
0 \cdot 50 \\
0 \cdot 55\end{array}$ & $\begin{array}{l}0.14 \\
0.96 \\
0.53 \\
0.57\end{array}$ & $\begin{array}{l}0.13 \\
0.99 \\
0.27 \\
0.76\end{array}$ & $\begin{array}{l}0 \cdot 28 \\
0 \cdot 25 \\
0 \cdot 29 \\
0 \cdot 21\end{array}$ & $\begin{array}{l}0 \cdot 12 * \\
0 \cdot 36 \\
0 \cdot 44 \\
0 \cdot 33\end{array}$ & $\begin{array}{l}0 \cdot 14 \\
0 \cdot 32 \\
0 \cdot 40 \\
0 \cdot 33\end{array}$ & $\begin{array}{l}0 \cdot 10 \\
0 \cdot 36 \\
0 \cdot 33 \\
0 \cdot 25\end{array}$ \\
\hline & Total & $\ldots$ & $\ldots$ & $\ldots$ & $7 \cdot 83$ & $9 \cdot 16$ & $8 \cdot 83$ & $9 \cdot 19$ & $2 \cdot 03$ & $2 \cdot 23$ & $2 \cdot 20$ & $2 \cdot 14$ & $1 \cdot 03$ & $1 \cdot 24$ & $1 \cdot 19$ & $1 \cdot 04$ \\
\hline
\end{tabular}

* Statistically significant change following operation-Probability $P<0.01$.

from operation was marked for both years. In each group of children respiratory disease accounted for less illness in the second year than the first. This decline was most marked for throat infections. It would seem that children are referred for tonsillectomy at the age when they are susceptible to upper respiratory infections, throat infections in particular, and that a subsequent decline in these infections would have taken place without operation. If this study had been prolonged, then in time one might expect the incidence and duration of respiratory illness would become similar in operated and control groups. Nevertheless, the recorded benefit from tonsillectomy with adenoidectomy over the first 2 years was considerable; it gave a saving of more than 1,500 days confinement per 100 children in respect of respiratory infections.
Control children required more medical attendances for sore throats than for any other group of illness. As a result of tonsillectomy there was a 51 per cent. reduction in medical attention for respiratory disease, and throat disease made less demands on medical practitioners than colds, coughs, infectious disease, or gastro-intestinal upsets (Table XII).

One further criterion of ill-health was used in this study; the number of "severe" episodes of illness (Table XI). This confirmed the benefits from tonsillectomy, but showed a relative increase in severe coughs for the second post-operative year. The frequency of non-severe coughs was $0 \cdot 20$ and 0.24 respectively for control and operated cases in that year. There was no significant difference between the groups when the common respiratory diseases, colds

TABLE XII

MEAN MEDICAL ATTENDANCES PER YEAR OF CONTROL AND TONSILLECTOMIZED CHILDREN (2 TO 15 YEARS)

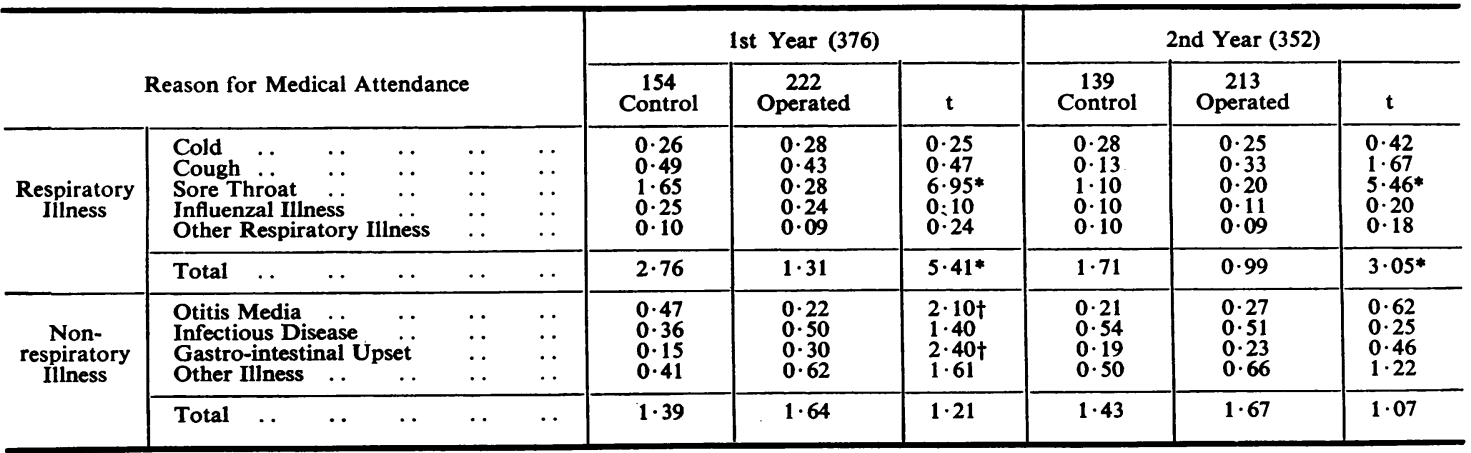

Significant changes: $* P<0.01$; $\quad$ † $P<0.05$ 
and coughs were considered together. In view of the inconsistency of the finding it is considered that the post-operative increase in severe coughs was a chance finding and represented overlap in the classification of illness.

(B) Non-Respiratory Illness.-The overall amount of non-respiratory illness was similar in control and tonsillectomized children, but this covers up a significant reduction in the incidence of otitis media resulting from operation (Table VIII). Comparison of the durations of ill-health and medical calls resulting from otitis media confirmed this result (Tables XI and XII). There was a 48 per cent. reduction in incidence, and a 70 per cent. reduction in school loss from these infections. Over the second year, otitis media was again more common in control children, but the previous high rate of infection was not seen, and hence the difference between the groups was small. In view of the seriousness of otitis media the probability of a marked improvement for even one year may be considered to justify an operation in some children.

Examination of Table $X$ reveals an increased loss of schooling from gastro-intestinal disease in operated children. This was confined to one age group, children 5 to 7 years old, and was seen over the first year only. In view of the inconsistency of the change and the low level of significance it can be regarded as a chance finding. One control child who had shown repeated minor gastro-intestinal upsets was later admitted to hospital for investigation, with a possible diagnosis of Hirschprung's disease; 32 days were spent in hospital and this "illness' was included with the miscellaneous group of "other illnesses" as the symptoms of diarrhoea, vomiting, and abdominal pain were not present. If this is regarded as gastro-intestinal illness, despite our definition, the records become statistically similar in control and operated children.

There were no other differences between operated and control children in respect of non-respiratory illness.

(4) Results of tonsillectomy With AdenoidecTOMY ON CHILDREN OF Different Age Groups

It was considered worthwhile to see whether the consistent benefits from operation in respect of throat disease and otitis media were common to children of the following age groups:

(i) 2 to 4 years inclusive at the start of follow-up. These were mainly pre-school children.

(ii) 5 to 7 years-the peak years for tonsillectomy (Fig. 2). These were early school attenders.

(iii) 8 to 15 years. These were older schoolchildren in whom the operation is less commonly performed. (i) Children aged 2 to 4 years.-There was a reduction in the rate of throat disease from 3.0 episodes in controls to $\mathbf{0 . 2}$ after operation in the first year, and from $2 \cdot 1$ to 0.03 in the second year (Table XIII).

\section{TABLE XIII}

INFLUENCE OF AGE ON ILLNESS DUE TO SORE THROAT IN CONTROL AND TONSILLECTOMIZED CHILDREN

\begin{tabular}{|c|c|c|c|c|c|}
\hline \multirow{2}{*}{$\begin{array}{l}\text { Incidence of } \\
\text { Sore Throat }\end{array}$} & \multirow{2}{*}{$\underset{\substack{\text { Group } \\
\text { (yrs) }}}{\text { Age }}$} & \multicolumn{2}{|c|}{ 1st Year } & \multicolumn{2}{|c|}{ 2nd Year } \\
\hline & & $\begin{array}{l}\text { Con- } \\
\text { trol }\end{array}$ & $\begin{array}{l}\text { Oper- } \\
\text { ated }\end{array}$ & $\begin{array}{l}\text { Con- } \\
\text { trol }\end{array}$ & $\begin{array}{l}\text { Oper- } \\
\text { ated }\end{array}$ \\
\hline $\begin{array}{c}\text { No. of Episodes of } \text { Ill- } \\
\text { ness } \ldots\end{array}$ & $\begin{array}{l}2-4 \\
5-7 \\
8-15\end{array}$ & $\begin{array}{l}3.04 \\
1.80 \\
1.67\end{array}$ & $\begin{array}{l}0 \cdot 19 \\
0 \cdot 39 \\
0 \cdot 50\end{array}$ & $\begin{array}{l}2.06 \\
0.95 \\
0.76\end{array}$ & $\begin{array}{l}0 \cdot 03 \\
0 \cdot 33 \\
0 \cdot 43\end{array}$ \\
\hline No. of Severe Episodes & $\begin{array}{l}2-4 \\
5-7 \\
8-15\end{array}$ & $\begin{array}{l}2.88 \\
1.65 \\
1.49\end{array}$ & $\begin{array}{l}0.16 \\
0.35 \\
0.45\end{array}$ & $\begin{array}{l}1.94 \\
0.84 \\
0.59\end{array}$ & $\begin{array}{l}0.00 \\
0.23 \\
0.34\end{array}$ \\
\hline $\begin{array}{l}\text { Confinement to Bed } \\
\text { (days) }\end{array}$ & $\begin{array}{l}2-4 \\
5-7 \\
8-15\end{array}$ & $\begin{array}{l}5 \cdot 21 \\
3.91 \\
2.08\end{array}$ & $\begin{array}{l}0.13 \\
0.44 \\
0.76\end{array}$ & $\begin{array}{l}4.56 \\
1.96 \\
1.11\end{array}$ & $\begin{array}{l}0.00 \\
0.35 \\
0.43\end{array}$ \\
\hline School Loss (days) & $\begin{array}{l}2-4 \\
5-7 \\
8-15\end{array}$ & $\begin{array}{l}\overline{6} \cdot 82 \\
4 \cdot 98\end{array}$ & $\begin{array}{l}\overline{0.95} \\
1.07\end{array}$ & $\begin{array}{l}3 \cdot \overline{07} \\
2 \cdot 30\end{array}$ & $\begin{array}{l}\overline{0.52} \\
1.44\end{array}$ \\
\hline $\begin{array}{l}\text { Total Duration of Ill- } \\
\text { ness (days) } \ldots\end{array}$ & $\begin{array}{l}2-4 \\
5-7 \\
8-15\end{array}$ & $\begin{array}{r}17.45 \\
11.34 \\
8.63\end{array}$ & $\begin{array}{l}1 \cdot 16 \\
1 \cdot 54 \\
2 \cdot 28\end{array}$ & $\begin{array}{r}13 \cdot 17 \\
5 \cdot 39 \\
3 \cdot 28\end{array}$ & $\begin{array}{l}0 \cdot 00 \\
1 \cdot 22 \\
2 \cdot 14\end{array}$ \\
\hline $\begin{array}{l}\text { No. of Medical Attend- } \\
\text { ances }\end{array}$ & $\begin{array}{l}2-4 \\
5-7 \\
8-15\end{array}$ & $\begin{array}{l}2 \cdot 83 \\
1.61 \\
1 \cdot 14\end{array}$ & $\begin{array}{l}0.13 \\
0 \cdot 26 \\
0.41\end{array}$ & $\begin{array}{l}2.89 \\
1.00 \\
0.57\end{array}$ & $\begin{array}{l}0.00 \\
0.19 \\
0.32\end{array}$ \\
\hline
\end{tabular}

Operated children experienced only half as much otitis media as did corresponding controls (Table XIV).

\section{TABLE XIV}

INFLUENCE OF AGE ON OTITIS MEDIA IN CONTROL AND TONSILLECTOMIZED CHILDREN (2 TO 15 YEARS)

\begin{tabular}{|c|c|c|c|c|c|}
\hline \multirow{2}{*}{$\begin{array}{l}\text { Incidence of } \\
\text { Otitis Media }\end{array}$} & \multirow{2}{*}{$\underset{\text { Group }}{\text { Age }}$} & \multicolumn{2}{|c|}{ 1st Year } & \multicolumn{2}{|c|}{ 2nd Year } \\
\hline & & $\begin{array}{l}\text { Con- } \\
\text { trol }\end{array}$ & $\begin{array}{l}\text { Oper- } \\
\text { ated }\end{array}$ & $\underset{\text { trol }}{\text { Con- }}$ & $\begin{array}{l}\text { Oper- } \\
\text { ated }\end{array}$ \\
\hline $\begin{array}{c}\text { No. of Episodes of Ill- } \\
\text { ness } \ldots\end{array}$ & $\begin{array}{l}2-4 \\
5-7 \\
8-15\end{array}$ & $\begin{array}{l}0.33 \\
0.42 \\
0.18\end{array}$ & $\begin{array}{l}0.16 \\
0.24 \\
0.02\end{array}$ & $\begin{array}{l}0.61 \\
0.17 \\
-\end{array}$ & $\begin{array}{l}0.31 \\
0.14 \\
0.04\end{array}$ \\
\hline No. of Severe Episodes & $\begin{array}{l}2-4 \\
5-7 \\
8-15\end{array}$ & $\begin{array}{l}0.29 \\
0.35 \\
0.16\end{array}$ & $\begin{array}{c}0.06 \\
0.18 \\
-\end{array}$ & $\begin{array}{l}0.44 \\
0.15 \\
-\end{array}$ & $\begin{array}{l}0 \cdot 25 \\
0 \cdot 10 \\
-\end{array}$ \\
\hline Confinement to Bed & $\begin{array}{l}2-4 \\
5-7 \\
8-15\end{array}$ & $\begin{array}{l}0.29 \\
0.68 \\
0.24\end{array}$ & $\begin{array}{c}0.25 \\
0.11 \\
-\end{array}$ & $\begin{array}{c}0.33 \\
0.17 \\
-\end{array}$ & $\begin{array}{l}0.31 \\
0.14 \\
-\end{array}$ \\
\hline School Loss (days) & $\begin{array}{l}2-4 \\
5-7 \\
8-15\end{array}$ & $\begin{array}{l}\overline{1.11} \\
0.65\end{array}$ & $\overline{0.39}$ & $\overline{0.45}$ & $\overline{0.39}$ \\
\hline $\begin{array}{c}\text { Total Duration of Ill- } \\
\text { ness (days) } \ldots\end{array}$ & $\begin{array}{l}2-4 \\
5-7 \\
8-15\end{array}$ & $\begin{array}{l}1.42 \\
1.91 \\
0.96\end{array}$ & $\begin{array}{c}0.34 \\
0.80 \\
-\end{array}$ & $\begin{array}{l}2.61 \\
0.71 \\
-\end{array}$ & $\begin{array}{l}1.31 \\
0.52 \\
-\end{array}$ \\
\hline $\begin{array}{c}\text { No. of Medical Attend- } \\
\text { ances }\end{array}$ & $\begin{array}{l}2-4 \\
5-7 \\
8-15\end{array}$ & $\begin{array}{l}0.46 \\
0.56 \\
0.35\end{array}$ & $\begin{array}{l}0.22 \\
0.32 \\
0.02\end{array}$ & $\begin{array}{l}0.72 \\
0.21 \\
-\end{array}$ & $\begin{array}{l}0.53 \\
0.30 \\
0.04\end{array}$ \\
\hline
\end{tabular}


With the small numbers in this age group this reduction in the incidence of otitis media was not statistically significant but, taken in conjunction with the systematic reduction in ear disease by other criteria of assessment over both years, it probably represents a genuine improvement from tonsillectomy and adenoidectomy.

In these children the rate of medical attendance was higher and the duration of illness at different levels of severity was longer than in other age groups. In unoperated children, illness accounted for 38 days home confinement in the first year, of which 17 days were caused by throat disease. In tonsillectomized children, the mean home confinement was 18 days, of which throat disease contributed only one day. It was noteworthy that in this age group, 47 to 48 per cent. of all medical attendances in control cases were for throat disease; after operation, this was reduced to less than 2 per cent. of attendances over 2 years. The results of tonsillectomy in these pre-school children were striking. There was a 44 per cent. reduction in respiratory illnesses. A mean saving of $\mathbf{3 1}$ days home confinement over 2 years was double the benefit seen for the whole population ( 2 to 15 years).

(ii) Children aged 5-7 years.-Throat disease was most frequent and gave more prolonged ill-health in unoperated children aged 2 to 4 years, where the high rate of infection continued through the second year of study (Table XIII). With children aged 5 to 7 years there was an early benefit from tonsillectomy. However, in corresponding controls, there was a 50 per cent reduction in the incidence and duration of throat disease over the second year, and therefore the overall benefit from operation was less marked than in younger children. In addition to a post-operative reduction in otitis media by 43 per cent. (Table XIV), there was an improvement in respect of chronic catarrhal disease. The latter had not been seen in pre-school children.

There seems little doubt from these figures that tonsillectomy has a place in children aged 5 to 7 years. Over a 2-year period it affected a saving of 1,435 days home confinement per 100 children studied. However, on the basis of these results, it is probable that operation would not generally be justified except to give a benefit over the year immediately following referral to hospital. Spontaneous improvement is rapid in these children, and children should be reassessed before operation in centres where there is a long waiting list. (iii) Children aged 8 to 15 years.-Here the changes were broadly similar to those in younger children, but the degree of post-operative benefit was less. The mean incidence of throat disease in controls was 1.67 episodes per year for the first year, and had reduced spontaneously to 0.76 per year in the second year. In operated children, the rates were 0.50 and 0.43 for the two years (Table XIII). The post-operative improvement was only significant for the first year. Over both years controls had a higher incidence of chronic catarrhal illness; the incapacity from this was slight, and the probability of reducing this illness cannot weigh heavily in favour of operation in a doubtful case.

Otitis media was infrequent in older school children (Table XIV) but it was noticeable that, over the first year, eight severe attacks occurred in the control group but none in the operated group.

The overall health picture in this age group showed a 34 per cent. reduction in confinement from illness for the first year after tonsillectomy. This was a significant difference, but represented a mean saving of only 6 days ill-health, or 4 days' schooling, in return for an operation which will probably require an absence from school of one week or more. The improvement from tonsillectomy seen in the second year was very small. The natural history of throat disease in older school children was such that a high degree of immunity was conferred spontaneously by the second year of the follow-up. It should be remembered that children were not included in this survey if they needed urgent tonsillectomy at the time of assessment. The result obtained here does not conflict with the value of urgent operation in a small number of patients. However, the surgeon must balance the disadvantages of morbidity from operation and the schooling lost through hospital admission against the reduced expectation of benefit in this group.

\section{(5) Developmental and Behavioural Disorpders}

At each visit routine inquiries were made concerning any disturbances of behaviour or development, such as speech defects and bedwetting. Minor emotional upsets were frequent, particularly fears of the dark. A child's behaviour was considered to be abnormal when these disturbances became the subject of repeated comment, or when a temporary upset was of a more severe nature. The latter usually followed a particular incident-an accident, infection, or operation. Reports of timidity, occasional 
nightmares, or anxieties before starting school were considered to be within the limits of normal behaviour.

The incidence of disturbances was slightly higher in unoperated children (Table XV), but the difference in proportions of control and operated children affected were not statistically significant $(\mathrm{PC}-\mathrm{PT}+\mathrm{A}$ $=0.017$, compared with s.e. $=0.034$ for the first year; $\mathrm{PC}-\mathrm{PT}+\mathrm{A}=0.044$, and s.e. $=0.036$ for the second year). Bedwetting was considered abnormal when seen in a child of 5 years or more, minor lapses with passing illness being excluded. The incidence was closely comparable in both groups of children. Though a recurrence of enuresis was related to the tonsillectomy in four children, it would seem that operation is only one of the predisposing upsets, and is statistically not important in the light of the overall health picture. Over the 2-year follow-up there was no evidence that tonsillectomized children were more liable to show behaviour or developmental upsets than corresponding controls. It may be relevant to know that children were always admitted to the wards on the day before the operation, and general anaesthesia was preceded by the administration of a barbiturate, many children being already asleep on arrival in the anaesthetic room.

\section{TABLE XV}

INCIDENCE OF BEHAVIOURAL AND DEVELOPMENTAL UPSETS

\begin{tabular}{|c|c|c|c|c|c|c|c|c|}
\hline \multirow{3}{*}{ Upsets } & \multicolumn{4}{|c|}{ 1st Year (376) } & \multicolumn{4}{|c|}{ 2nd Year (352) } \\
\hline & \multicolumn{2}{|c|}{$\begin{array}{c}154 \\
\text { Control }\end{array}$} & \multicolumn{2}{|c|}{$\begin{array}{c}222 \\
\text { Operated }\end{array}$} & \multicolumn{2}{|c|}{$\begin{array}{c}139 \\
\text { Control }\end{array}$} & \multicolumn{2}{|c|}{$\begin{array}{c}213 \\
\text { Operated }\end{array}$} \\
\hline & No. & $\begin{array}{c}\text { Per } \\
\text { cent. }\end{array}$ & No. & $\begin{array}{c}\text { Per } \\
\text { cent. }\end{array}$ & No. & $\begin{array}{c}\text { Per } \\
\text { cent. }\end{array}$ & No. & $\begin{array}{l}\text { Per } \\
\text { cent. }\end{array}$ \\
\hline $\begin{array}{l}\text { Enuresis } \\
\text { Speech Defects } \\
\text { Other Upsets .. }\end{array}$ & $\begin{array}{r}10 \\
5 \\
9\end{array}$ & $\begin{array}{l}6 \cdot 5 \\
3 \cdot 2 \\
5 \cdot 8\end{array}$ & $\begin{array}{r}14 \\
3 \\
17\end{array}$ & $\begin{array}{l}6 \cdot 3 \\
1 \cdot 4 \\
7 \cdot 7\end{array}$ & $\begin{array}{r}10 \\
3 \\
13\end{array}$ & $\begin{array}{l}7 \cdot 2 \\
2 \cdot 2 \\
9 \cdot 4\end{array}$ & $\begin{array}{r}10 \\
3 \\
15\end{array}$ & $\begin{array}{l}4.7 \\
1.4 \\
7.0\end{array}$ \\
\hline Total .. & $22^{*}$ & $14 \cdot 3$ & $28^{*}$ & $12 \cdot 6$ & $21^{*}$ & $15 \cdot 1$ & $23^{*}$ & $10 \cdot 8$ \\
\hline
\end{tabular}

* Enuresis and speech defects were present in several children showing other upsets.

\section{(6) Complications of Tonsillectomy With ADENOIDECTOMY}

Under this heading were collected all illnesses which might reasonably be related to the performance of the operation, the giving of the anaesthetic, or the hospitalization entailed. Generally, these illnesses started within 1 or 2 weeks of the date of operation.

Out of 222 operated children who were followedup for one year or more, complications were seen in
$17 \cdot 6$ per cent.; this figure was made up as follows:

\begin{tabular}{l|lrr|r|r}
\hline \multicolumn{3}{c|}{ Complications } & & No. & \multicolumn{1}{c}{ Per } \\
cent.
\end{tabular}

Only one of these children required readmission to hospital, but four others were kept in hospital for longer than usual because of haemorrhage or pyrexia. Primary haemorrhage occured in five children $(2.25$ per cent. of operations). In four of these, the child was returned to the theatre and the bleeding which came from the adenoid bed was stopped. In the fifth child bleeding soon ceased. Secondary haemorrhage was less frequent; one child was readmitted to hospital for chemotherapy.

The relative preponderance of otitis media over other infections illustrates the direct relationship between nasopharyngeal operation and middle ear infection. Otitis media was seen in $3 \cdot 1$ per cent. of children, whereas the other infections, occurring in the urinary tract, throat (excluding secondary haemorrhage), conjunctiva, and chest totalled only 2.7 per cent. Acute nephritis was the only serious illness to follow operation in this series.

General post-operative debility with or without some intermittent pyrexia was seen in five children ( $2 \cdot 25$ per cent.). It was a prominent cause of delay in the return of children to school. No relationship was demonstrated between the occurrence of debility and excessive loss of blood at or after the operation or length of anaesthesia.

The commonest post-operative complications were the group of behavioural upsets and enuresis. These were seen in twelve children, one out of every nineteen operations. None was severe, none required any home confinement, and only one was so prominent that the parents sought medical attention. Nevertheless, these upsets were a marked source of anxiety to the family, particularly as it was common for them to continue for several weeks-in one child 
for more than 12 months. A return of enuresis in a previously dry child was seen after 1.8 per cent. of operations, and lasted for varying periods up to 6 months. The other behavioural upsets were combinations of prominent fears, tantrums, maternal dependance, nightmares, and aggressiveness.

Complications of operation were most common in preschool children, and least common in children over 8 years old (Table XVI).

\section{TABLE XVI}

AGE DISTRIBUTION OF COMPLICATIONS OF TONSILLECTOMY AND ADENOIDECTOMY IN 222 CHILDREN

\begin{tabular}{|c|c|c|c|c|}
\hline \multirow{2}{*}{$\underset{\text { (yrs) }}{\text { Age }}$} & \multicolumn{2}{|c|}{ Behavioural Upsets } & \multicolumn{2}{|c|}{ Total Complications } \\
\hline & No. & $\begin{array}{l}\text { Per cent. } \\
\text { Incidence }\end{array}$ & No. & $\begin{array}{l}\text { Per cent. } \\
\text { Incidence }\end{array}$ \\
\hline $\begin{array}{l}2-4 \\
5-7 \\
8-15\end{array}$ & $\begin{array}{l}4 \\
7 \\
1\end{array}$ & $\begin{array}{r}12 \cdot 5 \\
5.3 \\
1.7\end{array}$ & $\begin{array}{r}8 \\
26 \\
5\end{array}$ & $\begin{array}{r}25.0 \\
19.7 \\
8.6\end{array}$ \\
\hline $2-15$ & 12 & $5 \cdot 5$ & 39 & $17 \cdot 6$ \\
\hline
\end{tabular}

Behavioural upsets accounted for 50 per cent. of the complications in children under 5 years. Out of twelve behavioural upsets related to tonsillectomy, ten occurred in children aged 6 years or less. Comparison of the total complications in children under 7 years of age with those over seven, yields a difference in proportions of $0 \cdot 121$, compared with a standard error of 0.058 . A larger study is needed to show if the higher incidence of complications in younger children is real, but the evidence suggests that there is a definite risk of behavioural disorder.

\section{(7) Illness in Control ChILdRen WithdRaWN FROM THE SURVEY}

It was agreed that, if circumstances changed during the follow-up of a control child, and there arose a definite and urgent need for operation, the child would be withdrawn from the study so that this could proceed. Out of 182 allocated controls, 21 were withdrawn during their first year, and 13 during the second. These losses were distributed between the youngest and middle age groups in the expected ratio, five from children aged 2 to 4 , and 25 from children aged 5 to 7 years. There were only four losses from older children. These children had been referred again to the surgeon by general practitioners, or school medical officers in view of the deterioration in health. The decision to withdraw a child was made on a clinical appraisal, but statistical comparison of these children with other controls confirmed a marked difference in the amount of illness suffered. In order to obtain a comparable group of controls, it is necessary to take into account the seasonal and age variations in the incidence of infections. The former is the major factor, for the incidence of different groups of illness has shown to be similar in pre-school and early school children in the first year of follow-up. To overcome these difficulties, each child withdrawn from the survey was matched with a completed control as follows:

(a) As exactly as possible for the starting date of observation.

(b) The closest match for age.

(c) Where possible a child of the same sex.

The mean ages of the two groups so obtained were 5.71 and 6.08 years respectively. Illness occurring up to the time a child was withdrawn for tonsillectomy was then compared with illness over the same period in the selected and comparable control. The periods up to withdrawal were variable, from 1 to 20 months, hence the figures for illness relate to the mean period of observation, 9.5 months. The withdrawn cases required twice the control rate of medical attention and confinement to bed; a mean loss of school of 22 days per $\mathbf{9 \cdot 5}$ months compared unfavourably with 14 days over the same period in other children who were not given operation (Table XVII, overleaf).

The total duration of illness was $\mathbf{4 0}$ days per child, equivalent to $6 \frac{1}{2}$ weeks' home confinement per year. Clearly these children were a special group, and it was proper to have removed them from the trial.

The higher rate of illness in withdrawn cases was principally due to throat infections. The duration of this was $26 \cdot 9$ days compared with $7 \cdot 2$ for the same period in other controls. If these children had continued as controls, one would have expected the relative benefit from tonsillectomy to be greater than was observed. It is, however, unlikely that the discontinuation of only four controls over 8 years, can have materially affected the poor results of operation in that age group as a whole. In view of the health records of withdrawals in that age group, one may consider that tonsillectomy is justified in a small number of "routine" cases despite evidence to the contrary for the age group as a whole. With regard to the age groups 5 to 7 and 2 to 4 years, the evidence of withdrawn children adds further support to the case for tonsillectomy in selected cases. 
TABLE XVII

ILLNESS IN 34 CHILDREN WITHDRAWN FROM THE SURVEY TO HAVE OPERATION AND 34 MATCHED CONTROLS AVERAGE FOLLOW-UP 9.5 MONTHS

\begin{tabular}{|c|c|c|c|c|c|c|c|c|}
\hline Illness & Cases & & & $\begin{array}{l}\text { No. of } \\
\text { Episodes } \\
\text { of Illness }\end{array}$ & $\begin{array}{l}\text { School Loss } \\
\text { (days) }\end{array}$ & $\begin{array}{c}\text { Total } \\
\text { Duration } \\
\text { of Illness }\end{array}$ & $\begin{array}{l}\text { No. of } \\
\text { Medical } \\
\text { Attendances }\end{array}$ & $\mathbf{P}$ \\
\hline Sore Throat & $\begin{array}{l}\text { Withdrawn } \\
\text { Matched Control } \\
\text { t } \ldots \quad \text {. }\end{array}$ & $\begin{array}{l}\cdots \\
\cdots\end{array}$ & $\begin{array}{l}\ddot{*} \\
\ddot{*}\end{array}$ & $\begin{array}{l}4 \cdot 0 \\
1 \cdot 3 \\
(5 \cdot 28) *\end{array}$ & $\begin{array}{c}15 \cdot 9 \\
4 \cdot 4 \\
(4 \cdot 81)^{*}\end{array}$ & $\begin{array}{c}26 \cdot 9 \\
7 \cdot 2 \\
(5 \cdot 42) *\end{array}$ & $\begin{array}{l}4 \cdot 4 \\
1 \cdot 1 \\
(5 \cdot 88) *\end{array}$ & $\mathbf{P}<.001$ \\
\hline All Other Illness . . & $\begin{array}{l}\text { Withdrawn } \\
\text { Matched Control } \\
\text { t } \ldots \quad \ldots\end{array}$ & $\begin{array}{l}\cdots \\
\cdots\end{array}$ & $\begin{array}{l}\cdots \\
\cdots\end{array}$ & $\begin{array}{l}4 \cdot 8 \\
5 \cdot 0 \\
(0 \cdot 27)\end{array}$ & $\begin{array}{l}6 \cdot 3 \\
9 \cdot 9 \\
(1 \cdot 33)\end{array}$ & $\begin{array}{l}13 \cdot 5 \\
17 \cdot 5 \\
(0 \cdot 93)\end{array}$ & $\begin{array}{l}1 \cdot 8 \\
2 \cdot 0 \\
(0 \cdot 41)\end{array}$ & \\
\hline Total & $\begin{array}{l}\text { Withdrawn } \\
\text { Matched Controi } \\
\ldots\end{array}$ & $\begin{array}{l}\cdots \\
\cdots\end{array}$ & $\begin{array}{l}\cdots \\
\cdots\end{array}$ & $\begin{array}{l}8 \cdot 8 \\
6 \cdot 4 \\
(2 \cdot 10)\end{array}$ & $\begin{array}{l}22 \cdot 3 \\
14 \cdot 3 \\
(2 \cdot 07)^{*}\end{array}$ & $\begin{array}{l}40 \cdot 5 \\
24 \cdot 7 \\
(2 \cdot 94) *\end{array}$ & $\begin{array}{l}6 \cdot 2 \\
3 \cdot 1 \\
(4 \cdot 46)^{*}\end{array}$ & \\
\hline
\end{tabular}

- Statistically significant.

(8) Evidence of CoMpleteness of Operation AND THE INFLUENCE OF REMNANTS

Children were examined for tonsillar remnants 12 months after operation. Any visible lymphoid tissue in the tonsillar fossae was recorded but the parents were not told of the existence of such remnants, because it was felt that, by drawing attention to this finding, the future illness reports might be prejudiced. One or two small follicles of lymphoid tissue were commonly seen encroaching from the lingual tonsils. If their presence gave a predisposition to throat infections, it would be surprising if any benefit resulted from the removal of tonsils and adenoids. Nevertheless, it was thought worthwhile to see whether the presence of a larger remnant influenced the result of operation. For this purpose a remnant was defined as a mass of lymphoid tissue on one or both tonsillar fossae which showed the presence of crypts, or an aggregation of lymphoid follicles covering one-sixth or more of one fossae.

Remnants were found in fifteen out of 222 operated children ( 7 per cent.). The majority of these were extensions into the tonsillar fossae from lymphoid tissue at the base of the tongue. The highest incidence was in pre-school children, of whom 16 per cent. had remnants-an expression of the remarkable powers of proliferation of lymphoid tissue.

The incidence of illness in children with remnants was compared with that in matched cases showing no remnants (Table XVIII). The children were matched for the date of operation, age, and sex, to eliminate seasonal and other variations. There were no overall differences in the incidence of respiratory or non-respiratory illness; the rate of throat disease was more than twice as high in children with remnants, but this represented a small increase which was not statistically significant.

\section{TABLE XVIII}

MEAN EPISODES OF ILLNESS PER YEAR IN 15 CHILDREN WITH REMINANTS AND A MATCHED GROUP WITHOUT REMNANTS

\begin{tabular}{|c|c|c|c|c|c|c|}
\hline \multirow{2}{*}{ Illness } & \multicolumn{3}{|c|}{ 1st Year } & \multicolumn{3}{|c|}{ 2nd Year } \\
\hline & $\begin{array}{l}\text { Rem- } \\
\text { nants }\end{array}$ & $\begin{array}{c}\text { No } \\
\text { Rem- } \\
\text { nants }\end{array}$ & $\mathbf{t}$ & $\begin{array}{l}\text { Rem- } \\
\text { nants }\end{array}$ & $\begin{array}{c}\text { No } \\
\text { Rem- } \\
\text { nants }\end{array}$ & $t$ \\
\hline $\begin{array}{l}\text { Sore Throat . } \\
\text { Total Respiratory Iil- } \\
\text { ness } \\
\begin{array}{ccc}\text { Non-Respiratory } & \text { Iil- } \\
\text { ness } & \text {.. } & \ldots\end{array}\end{array}$ & $\begin{array}{l}0 \cdot 73 \\
3 \cdot 27 \\
1 \cdot 93\end{array}$ & $\begin{array}{l}0 \cdot 27 \\
3 \cdot 53 \\
2 \cdot 27\end{array}$ & $\begin{array}{l}1 \cdot 91 \\
0 \cdot 42 \\
0 \cdot 59\end{array}$ & $\begin{array}{l}0 \cdot 47 \\
2 \cdot 87 \\
2 \cdot 60\end{array}$ & $\begin{array}{l}0 \cdot 20 \\
2 \cdot 67 \\
2 \cdot 47\end{array}$ & $\begin{array}{l}1 \cdot 51 \\
0 \cdot 30 \\
0 \cdot 17\end{array}$ \\
\hline Total & $5 \cdot 20$ & $5 \cdot 80$ & 0.58 & $5 \cdot 47$ & $5 \cdot 13$ & 0.30 \\
\hline
\end{tabular}

\section{Discussion}

The distribution of different groups of illness in the present study was different from that obtained by other workers who observed illness in a community. In Newcastle-on-Tyne, Miller, Court, Walton, and Knox (1960) found that respiratory illness accounted for less than $\mathbf{5 0}$ per cent. of all incidents occurring in children under 6 years of age. This compares with 66 per cent. in our unoperated children and 57 per cent. after tonsillectomy with adenoidectomy. The latter result relates to a selected population of children referred to hospital with tonsil trouble in whom it would be expected that their susceptibility to respiratory infections was then at its height.

The studies of Badger and others (1953) and also of van Volkenburgh and Frost (1933) have shown that with increasing age a child develops resistance 
to infections. In the Cleveland study a rising incidence of common respiratory infections was seen up to the age of 3 years, thereafter a fall with increasing age. Brimblecome and others (1958) found the maximum incidence of colds and chronic catarrh in the age group 0 to 4 years, but for sore throats it was 10 to 16 years. In the present study the highest rate of respiratory illness and throat disease was found in children who started follow-up when under 5 years of age. There was a decline in the occurrence of respiratory disease in unoperated children of all age groups over a 2 year period, but the fall was least marked in pre-school children. Only 14 per cent. of our sample were under 5 years of age at the start of the follow-up. It is likely they were not typical of their age group in the general community, but in those few who became candidates for tonsillectomy, there was a continuing high rate of throat disease. In older children there was a rapid acquisition of immunity to throat disease. In the unoperated population throat disease did not show the regular seasonal fluctuation of common colds, coughs and chest diseases. Downes (1950) and Frost and Gover (1932) studied the seasonal changes in the incidence of colds and found several winter peaks between September and May. In the present study, a high rate was seen from September to April, with a peak in December or January. Throat disease showed several minor peaks distributed irregularly throughout each year.

In the present study, children selected on the basis of uniform criteria were allocated for operation or control study. This was the only way of achieving a statistically satisfactory study but it introduced an ethical difficulty. This was overcome by excluding children clearly in need of an urgent operation, and others not requiring tonsillectomy, on currently acceptable standards. It is known that in some centres children in the intermediate group would have tonsillectomy after varying delays, whilst other practitioners would not suggest operation. There is no evidence that these "routine" cases come to serious harm from a delay of 2 years, and in some hospitals the waiting list is of this order. For these reasons, the survey method was considered to be ethically acceptable, with the proviso that should a child's condition change and urgent operation become necessary, he would be withdrawn from the study.

This study does not compare the results of tonsillectomy with the results of any specified medical treatment. The work of Brimblecome and others (1958) showed that the majority of upper respiratory infections were not bacterial in origin, and many others were not attributable to known viruses. It is one problem to ensure constancy of treatment in 600 children, and yet another to decide what is to be good medical treatment for illness which is caused by unidentified organisms. The assumption was made that the management of illness in control and operated children would be adequate if left to the patients' own medical practitioners. The results assess the advantages or disadvantages of operation over the normal practice of medical treatment for the conditions described. The field workers acted only as observers and recorders of illness.

At one time or another, tonsillectomy has been recommended for almost every childhood illness from acute tonsillitis to mental retardation. Suggested indications divide themselves into two groups-local respiratory conditions and general upsets. In the latter group, Kaiser (1940) listed growing pains, rheumatic fever, nephritis, malnutrition, and retarded mental development. Only 10 years ago, Roberts (1952) commended tonsillectomy for children failing to thrive, and for the relief of various focal infections such as rheumatism and haematuria. In the present survey it was not possible to assess the place of tonsillectomy in the treatment of infrequent focal infections. This would require a different method of selection, or a much larger survey to obtained sufficient cases. Nevertheless, with the exception of otitis media, there was no evidence that tonsillectomized children had more or less non-respiratory illness than unoperated cases.

Illingworth (1950) and Macbeth (1950) did not list any general illnesses as indications for tonsillectomy, but suggested that these were confined to local conditions of the upper respiratory tract. Macbeth regarded repeated attacks of acute (throat) infection as an absolute indication for tonsillectomy. The present study supports this only in respect of very young children. In the older school child it will be best to defer operation where there is a short history of recurrent throat infections, and the length of the history will be more important here than the frequency of upsets.

Wolman (1956), in a survey of physicians in the United States, found that tonsillectomy with adenoidectomy was recommended by 77 per cent. for the relief of recurrent or chronic otitis media. Fry (1957) stated that recurrent otitis media was one of the principal reasons for recommending tonsillectomy with adenoidectomy from his practice; it was seen in 24 out of forty children referred for the 
operation over a 10-year period. A reduction in otitis media after the combined operation is confirmed here, but it is necessary to examine this finding in relation to the two parts of the operation to see if adenoidectomy alone gives a similar result. This is the subject of another survey which is to be reported later.

The timing of the operation has recently been a source of agreement between physicians and surgeons. Illingworth (1950) states that "tonsils should practically never be removed before the age of 4 , and rarely before the age of 5 or 6". Gale (1951), Dey (1952), and other workers suggest that, wherever possible, tonsillectomy should be deferred until the child reaches the age of 5 years; yet Brimblecombe and others (1958) found that the pre-school child was the most likely to introduce infection into a family. Only 14 per cent. of the present sample were under 5 years old. Either general practitioners were reluctant to refer them or else few very young children suffered from recurrent throat disease. Nevertheless, in those studied, a high rate of throat disease continued for 2 years unless operation was performed. It was here that the best results of tonsillectomy were seen.

This study was confined to children who were aged 2 to 15 years when first seen by the surgeon. They had a common criterion, namely three recent episodes of throat disease, or respiratory illness with cervical adenitis. One may consider the influence of tonsillectomy and adenoidectomy in these cases as follows:

(1) The principal benefit is the relief from throat disease, a result which holds good in all age groups studied. There is also a reduction in chronic catarrhal disease.

(2) The best results of operation are in children under 5 years of age who are in a phase of high susceptibility to throat disease.

(3) In young schoolchildren aged 5 to 7 years, tonsillectomy is of value where there is a history of three throat infections over the past 12 months, if it is possible to offer the operation without delay. The results will be less satisfactory if performed after a delay of 12 months on the waiting list, as many children will have developed immunity to throat disease; the small benefit which can be expected from the further reduction in throat disease may not compensate for the morbidity and hospitalization entailed in performing the operation. The surgeon will find that regular reassessment of waiting list cases will repay the time spent, particularly in children over 5 years of age.

(4) The statistical result in the age group 8 to 14 years does not support the place of "routine" tonsillectomy in children with three recent throat infections. These children rapidly acquire immunity to throat disease. However, this study does not distinguish between a child of 8 years and a child of 14 years. The number of cases in each individual year of age over 8 years was small; of the total population only 34 were aged 8 years, and only nine were aged 12 years. These groups were too small in themselves for a statistical result, but it is reasonable to assume that the differences between the age groups 5 to 7 years and 8 to 15 years represent progressive changes, and that the results of operation are less good as age increases. At the age of 5 years early operation is justified in these children, but at 10 years the surgeon may wish to defer his decision. The decision to operate in older school children can then be taken in selected cases in whom the development of immunity is less rapid than usual; the length of the history of throat infections will thus be more important than the frequency of infections over the past year.

(5) A reduction in otitis media follows the combined operation.

(6) An increase in illness due to coughs and chest disease is explained by overlap in classifying disease, for it was accompanied by a similar reduction in colds, also limited to the second year of follow-up. In any case, the increased illness it caused was small in comparison with the improvement in respect of throat disease.

(7) Tonsillectomy had no influence on the incidence or severity of other respiratory or nonrespiratory disease.

The incidence of tonsil tags has been variously reported by different workers. Sputh and Sputh (1946) found that 80 per cent. of 285 tonsillectomized patients had remnants, whilst Gooch and Lillie (1948) reported 22 per cent. of tags in operated patients seen at the Mayo Clinic. Other workers have reported between 50 and 80 per cent. In the present study, remnants were found in only 7 per cent. of patients seen one year after tonsillectomy. 
These variations may be attributed to three factors:

(1) The criteria for diagnosis of a tonsil remnant have been variable. McLaggan (1930) classified tags as covering one-quarter to the whole of the fossa, yet these were found in 49 per cent. of 100 school children. Bradley (1930) found complete eradication of tonsil tissue in only 18 per cent. In a series of 1,000 cases Hyde (1951) reported that 68 per cent. had remnants containing crypts. In the present study the criterion for a remnant was the presence of lymphoid tissue or follicles covering one-sixth or more of one fossa, or containing a crypt.

(2) The use of certain instruments such as the wire snare and tonsillotome has been regarded as a cause of remnants. In earlier surveys such as those of Rhoads and Dick (1928) and Campbell (1939) showing $70-80$ per cent. remnants in student girls, it is likely that the findings reflected in part the results of the guillotine procedure. These would not be expected to-day in any centre where dissection is the rule. In this survey, all the operations were carried out under the conditions of a major operation with general anaesthesia and a dissection technique.

(3) It is relevant to know the time which elapsed between operation and examination for remnants. Lymphoid tissue is labile, and the incidence at one year may be different from that at 10 years. In the series of Rhoads and Dick (1928), McLaggan (1930), Gooch and Lillie (1948), and other workers, the interval was variable, in some patients probably 15 to 20 years. Epstein (1937), who observed 540 children for up to 2 years after operation, noted hypertrophied lymphoid tissue in 336, particularly in children under 4 years of age. This finding is confirmed by the present work. Remnants, as defined, were seen in 15 per cent. of children under 5 compared with 5 per cent. in older children.

The aetiology of remnants has been attributed to microscopic extratonsillar lymphoid tissue. Baum (1919) demonstrated this histologically in the floor and pillars of the fossa. Others have stated it is the result of infection of residual tonsil tissue. In the present study, tags were only seen in the pole adjacent to the base of the tongue. In several, these appeared to be continuous with lingual follicles. Their marked occurrence in young children and in this position suggests that compensatory hypertrophy of residual or adjacent lymphoid follicles is a cause.

Various complaints have been attributed to tags. Kaiser (1930) noted that they predisposed to otitis media, cervical adenitis, sore throats, head colds, repeated fevers, and laryngitis. Comparison of fifteen children with remnants and fifteen matched cases does not confirm this. The overall health records of the two groups are similar, though the symptom of sore throat with an upper respiratory illness is more common when remnants are present. This finding relates to tags defined by an arbitrary definition, and may not true of the influence of clinically acceptable remnants. Nevertheless, it is clear that the good results of tonsillectomy described in this study apply both to "complete" tonsillectomy and to the overall practice of the operation.

Severe complications of tonsillectomy with adenoidectomy are relatively uncommon. Illingworth (1939) investigated 365 cases of nephritis. The operation had probably initiated the illness is 5 per cent., and had caused an exacerbation in 24 per cent. of 119 children having operation during the course of nephritis. In the present study, acute nephritis followed operation in one child out of 222 operations. Though a rare complication, the national incidence is probably sizeable.

The main complications of tonsillectomy with adenoidectomy were behaviour upsets (seen in 5.4 per cent.), haemorrage ( 3.6 per cent.), and otitis media (3.1 per cent.). Paton (1943) considered that both tonsillectomy with adenoidectomy and adenoidectomy alone increased the liability to ear infections in girls, whereas Kaiser (1940) showed that the early results of tonsillectomy were good. The former result has not been confirmed. It was clear from the present survey that, whilst otitis media was related to nasopharyngeal operation in a few cases, tonsillectomy with adenoidectomy reduced the subsequent liability to these infections.

Coleman (1949) analysed the fears and confusions experienced by children over hospital admission. Tonsillectomy is frequently the reason for a child's first separation from home and parents, hence it is nor surprising that behaviour disorders follow. Levy (1945) found evidence of emotional disturbance in 20 per cent. of operated children, and particularly in those aged 1 and 2 years. The low incidence in the present study may be related to satisfactory preparation, premedication, and general anaesthesia. Children were admitted to hospital one day before operation, and were familiar with their new surroundings and attendants before surgery. The predominance of these upsets in very young children has been confirmed, but it is in these children that tonsillectomy is of most value. There is no doubt that behaviour disorders are just as much 
a complication of operation as haemorrhage, and they may be very prolonged. This emphasizes the need to consider tonsillectomy as a major operation. Early admission, unrestricted visiting, and satisfactory premedication will help to allay the childs' anxieties, and it is hoped that the requirements will increasingly be met. In this study, behaviour disturbances followed operation in 5 per cent. of children. However, in the light of the subsequent health picture, operation was not an overwhelming cause. The overall incidence was similar in operated and control cases over a 2-year period, which indicates that a continuing high rate of illness predisposes to such disturbances in unoperated children. The occurrence of behaviour upsets cannot be regarded as a major contraindiation to the operation, but rather as a challenge to the hospital staff to satisfy the needs of young children.

\section{SUMMARY}

A controlled study of tonsillectomy is described, in which 413 successive non-urgent cases aged 2 to 15 years were selected from hospital clinics. A system of 2-monthly home visiting was used to obtain complete illness records. The results of tonsillectomy in one group of children were compared with the results of the usual medical treatment in control cases.

The distribution of illness in this population is described. The benefits from tonsillectomy were a relief from illness with sore throat, and a reduction in chronic nasal disease and otitis media. Children selected for study had in common a history of three or more recent episodes of throat disease or acute respiratory illness with enlargement of the cervical glands. In these cases the benefit from operation was less marked with increasing age.

As a result of this study the following suggestions are made:

(1) The best results of operation may be expected in those selected children under the age of 5 years who show a high susceptibility to throat disease with three or more episodes over the past 12 months.

(2) In young school children with a similar history a good result may be expected provided operation is performed without much delay. As a result of the early development of immunity to throat infections, the benefit from operation will generally be small if it is delayed for 12 months. There should thus be regular reassessment of these children if they are placed on the waiting list after a short history of recurrent throat disease.
(3) The surgeon will wish to balance the reduced expectation of benefit with increasing age against the disadvantages of the morbidity from operation and the hospitalization entailed, knowing that the statistical result in the age group 8 to 15 years does not support the value of tonsillectomy in children with a history of three recent episodes of throat disease. If operation is deferred in older children, follow-up will show that the development of immunity is rapid. Spontaneous relief from throat infection is the rule rather than the exception.

(4) In assessing the need for operation in older school children, the length of the history of throat disease will thus be more important than the frequency of infection over the past 12 months. A sizable morbidity from throat disease over 2 or more years may be regarded as evidence of slow development of immunity and as an indication for operation.

(5) Tonsillectomized children have less otitis media than unoperated controls. A further survey has been undertaken to see if this benefit is the result of tonsillectomy or of the associated adenoidectomy. This is to be reported in a subsequent paper.

(6) Tonsillectomy has no place in the relief of colds, coughs, influenzal disease, behaviour upsets, or other non-respiratory illness.

One child in six showed evidence of an upset which was related to the performance of the operation. The incidence of complications was highest in pre-school children; behaviour upsets were the most common group, but here operation was only one predisposing factory. During the 2-year follow-up the overall incidence of behaviour disturbances was similar in operated and control children.

Tonsillar remnants were found in 7 per cent. of operated children, and were three times as common in children under 5 years as in the rest. There was no evidence that remnants had an adverse effect on the early results of operation, though the complaint of sore throat with respiratory disease was more common when they were present.

A grant from the Nuffield Provincial Hospitals Trust was obtained at the request of Dr. D. G. Leys, who together with Dr. R. Doll, Dr. J. Fry, and Mr. J. F. Lipscomb formed a Steering Committee for this work. Besides my debt to them for advice and encouragement, I wish to thank Mrs. E. R. Baker and Mrs. J. Smalley for their untiring fieldwork. Mr. J. F. Lipscomb personally undertook the operations on all the survey children. 


\section{REFERENCES}

Badger, G. F., Dingle, J. H., Feller, A. E., Hodges, R. G., Jordan, W. S., and Rammelkamp, C. H. (1953). Amer. J. Hyg., 58, 31 .

Bakwin, H. (1958). J. Pediat., 52, 339.

Baum, H. L. (1919). Ann. Otol. (St. Louis), $28,37$.

Bradley, W. H. (1930). Arch. Dis. Childh., 5, 335.

Brimblecombe, F. S. W., Cruickshank, R., Masters, P. L., Reid, D. D., Stewart, G. T., and Sanderson, D. (1958). Brit. med. J., 1, 119.

Campbell, E. H. (1939). Arch. Otolaryng., 30, 863.

Coleman, L. D. (1949). Laryngoscope (St. Louis), 59, 709.

Dey, D. L. (1952). Med. J. Aust., 1, 510.

Dingle, J. H., Badger, G. F., Feller, A. E., Hodges, R. G., Jordan, W. S., and Rammelkamp, C. H. (1953). Amer. J. Hyg., 58, 16.

Downes, J. (1950). Amer. J. publ. Hlth, 40, 1512.

Epstein, I. M. (1937). Amer. J. Dis. Child., 53, 1503.

Frost, W. H., and Gover, M. (1932). Publ. Hlth Rep. (Wash.), 47, 1815.

Fry, J. (1957). Brit. med. J., 1, 124.

Gale, A. H. (1951). Ibid., 1, 133.

General Register Office (1956). “Census, 1951. Classification of Occupations". H.M.S.O., London.

Glover, J. A. (1948). Arch. Dis. Childh., 23, 1. (1950). Monthly Bull. Minist. Hlth, 9, 62.

Godwin, M. (1953). J. Laryng., 67, 153.

Gooch, J. O., and Lillie, H. I. (1948). Ann. Otol. (St. Louis), 57, 957.

Hadfield, E. H. (1950). Proc. roy. Soc. Med., 43, 327.

Hyde, T. L. (1951). J. Amer. med. Ass., 146, 1478.

Illingworth, R. S. (1939). Lancet, 2, 1013.

- (1950). Proc. roy. Soc. Med., 43, 317.
Johnston, J. A., and Watkins, T. W. (1954). J. Pediat., 44, 127.

Kaiser, A. D. (1930). J. Amer. med. Ass., 95, 837. (1931). Amer. J. Dis. Child., 41, 568. (1940). J. Amer. med. Ass., 115, 1151.

LeRiche, H., and Stiver, W. B. (1957). Canad. med. Ass. J., 77, 109.

Levy, D. M. (1945). Amer. J. Dis. Child., 69, 7.

Macbeth, R. G. (1950). Proc. roy. Soc. Med., 43, 324.

McCorkle, L. P., Hodges, R. G., Badger, G. F., Dingle, J. H., and Jordan, W. S. (1955). New Engl. J. Med., 252, 1066.

McLaggan, J. D. (1930). Lancet, 2, 1150.

Medical Research Council (1938). "Epidemics in Schools", M.R.C. Spec. Rep. Ser. No. 227. H.M.S.O., London.

Mertz, J. C. (1954). Milbank mem. Fd Quart., 32, 5.

Miller, F. J. W., Court, S. D. M., Walton, W. S., and Knox, E. G. (1960). "Growing up in Newcastle upon Tyne”, 1st ed., p. 13. Oxford University Press, London.

Paton, J. H. P. (1943). Quart. J. Med., 12, 119.

Registrar General (1948-58). "Statistical Reviews (England and Wales)." H.M.S.O., London.

Rhoads, P. S. and Dick, F. G. (1928). J. Amer. med. Ass., 91, 1149.

Roberts, M. (1952). J. Irish med. Ass., 31, 197.

Sputh, C. B. Jr., and Sputh C. B. Snr. (1946). J. Indiana med. Ass., 39, 401.

U. S. Vital Statistics (1950-55). Dept. Health, Education and Welfare. (Quoted from Bakwin, 1958).

Van Volkenburgh, V. A., and Frost, W. H. (1933). Amer.J. Hyg., 17, 122.

Walker, J. S. (1953). Arch. Otolaryng., 57, 664.

Wolman, I. J. (1956). Quart. Rev. Pediat., 11, 109. 